\title{
CAN NATURBANIZATION PROMOTE ENVIRONMENTALLY FRIENDLY BUILT-UP AREAS? A COMPARISON BETWEEN CADÍ-MOIXERÓ (CATALONIA, SPAIN) AND COMANA (ROMANIA) NATURAL PARKS
}

Antoni-Francesc Tulla ${ }^{1}$, llinca-Valentina Stoica ${ }^{2}$, Marta Pallarés-Blanch ${ }^{3}$, Daniela Zamfir ${ }^{4}$

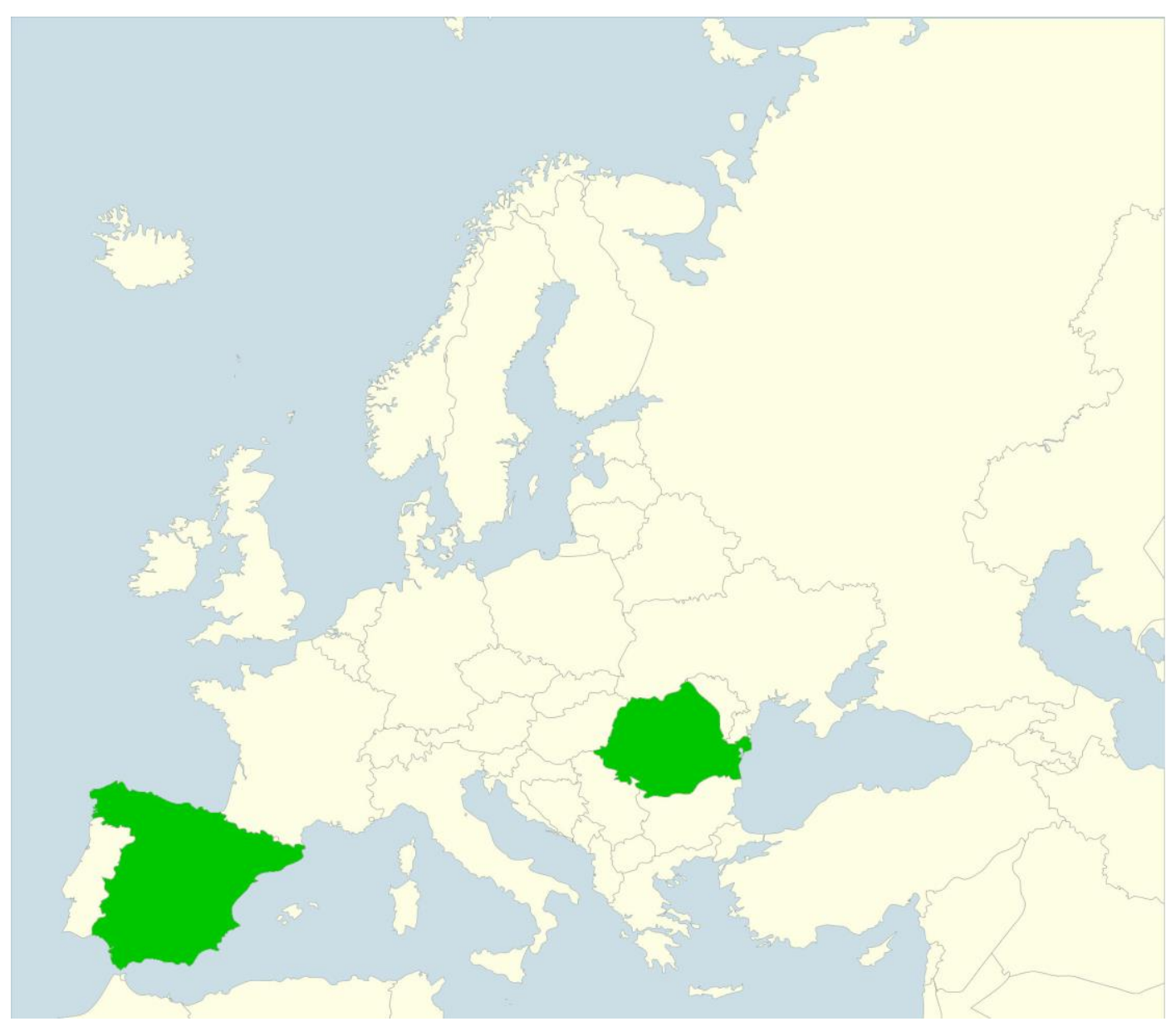

\footnotetext{
${ }^{1}$ Professor Antoni-Francesc Tulla, Department of Geography, Universitat Autònoma de Barcelona, 08193 Bellaterra, Catalonia, Spain; e-mail: antoni.tulla@uab.cat

2 Dr. Ilinca-Valentina STOICA, Interdisciplinary Centre for Advanced Research on Territorial Dynamics, Faculty of Geography, University of Bucharest, Bulevardul Nicolae Bălcescu 1, 01004 București, Romania; e-mail: vallys_2005@yahoo.com

${ }^{3}$ Marta Pallarès-Blanch, Consorci Alt Urgell XXI, Catalonia, Spain; e-mail: marta.pallares@gmail.com

${ }^{4}$ Daniela ZAMFIR, Interdisciplinary Centre for Advanced Research on Territorial Dynamics, Faculty of Geography, University of Bucharest, Bulevardul Nicolae Bălcescu 1, 01004 București, Romania; e-mail: irdanniela@yahoo.com
} 
Abstract: The study compares the on-going naturbanization processes in and around two Natural Parks under the impact of newcomers, but also tourists from Barcelona and Bucharest and their metropolitan areas. The landscape value of these areas attracts the urban population, which contributes to local sustainable development process but also promotes construction. New businesses associated with rural multifunctionality and value-added activities related to environmental quality were identified. New residents have contributed introducing responsible patterns of consumer, ecoentrepreneurship by women, recovery of abandoned buildings and intensification of rural-urban relationships. Negative impacts such as intensive construction of second homes, with a lower use, in some areas around Cadí-Moixeró threaten biodiversity and habitat connectivity. Insufficient integration of environmental policies, particularly in the Comana wetlands, reduces the potential for rural renewal. Research methods included a review of the counterurbanization literature and the statistical data related to processes of naturbanization in both areas, along with the conduct of 30 structured interviews with key local actors in each area. Naturbanization still offers the potential to enhance local development; however, it is urgent to assess social perspectives in natural parks management in order to achieve environmentally friendly built-up areas.

Key words: Built-up areas, Cadí-Moixeró NP, Comana NP, Naturbanization, Quality landscape, Barcelona, Bucharest.

Abstract: Naturbanizarea poate promova zone rezidențiale compatibile cu mediul înconjurător? O comparație între parcurile naturale Cadí-Moixeró (Catalonia, Spain) și Comana (Romania). Acest studiu compară procesul de naturbanizare în două parcuri naturale sub impactul noilor veniți dar și a turiștilor din Barcelona și București și zonele metropolitane ale acestora. Peisajul acestor zone atrage populația urbană, care contribuie la dezvoltarea locală sustenabilă dar și la apariția de noi construcții. Noile activități economice sunt asociate cu multifuncționalitatea rurală și cu valoarea adăugată relaționată cu calitatea mediului. Noii rezidenți au contribuit prin introducerea unor modele de consum responsabil, integrarea femeilor antreprenor, reconversia clădirilor abandonate și intensificarea relațiilor urban-rural. Efectele negative precum construcția reședințelor secundare (multe dintre acestea vacante) în anumite zone din jurul parcului natural Cadí-Moixeró, amenință biodiversitatea și conectivitatea habitatelor. Insuficienta integrare a politicilor de mediu, mai ales în parcul natural Comana, reduc potențialul reînnoirii rurale printr-o abordare integrată. Metodele de cercetare includ o prezentare a literaturii referitoare la procesul de contraurbanizare și a datelor statistice relaționate procesului de naturbanizare în ambele arii, împreună cu rezultatele a 30 de interviuri structurate aplicate în fiecare zonă unor actori cheie. Naturbanizarea prezintă potențial pentru a stimula dezvoltarea locală, însă, este urgent să se asigure o perspectivă socială în managementul parcurilor naturale pentru a se ajunge la o compatibilitate cu mediul înconjurător.

Cuvinte cheie: zone rezidențiale, Parcul Natural Cadí-Moixeró, Parcul Natural Comana, naturbanizare, peisaj atractiv, Barcelona, București.

Resum: Pot la naturbanització promoure àrees edificades compatibles amb el medi ambient? Comparació entre els parcs naturals Cadí-Moixeró (Catalunya, Espanya) i Comana (Rumania). Aquest estudi compara la naturbanització en dos parcs naturals sota l'impacte de nouvinguts però també de turistes de Barcelona i Bucarest $\mathrm{i}$ les seves àrees metropolitanes. Les noves activitats econòmiques es relacionen amb la multifuncionalitat rural i el valor afegit de la qualitat ambiental. Els nous residents han contribuït amb un consum responsable, la incorporació de dones emprenedores, la reconversió d'edificis antics abandonats i la intensificació de les relacions ciutat-camp. $\mathrm{Hi}$ ha impactes negatius com la construcció de segones 
residències infrautilitzades en algunes àrees a l'entorn del Cadí-Moixeró, perjudicant la biodiversitat i la connectivitat dels hàbitats. La integració insuficient de les polítiques mediambientals, especialment en els aiguamolls de Comana, redueix el potencial d'un enfocament integrat de renovació rural. La metodologia inclou una revisió bibliogràfica sobre naturbanització, un recull estadístic i els resultats de 30 entrevistes a actors clau a cada àrea. La naturbanització encara te potencial per a millorar el desenvolupament rural, encara que es imprescindible incorporar-hi un enfocament social a la gestió dels parcs naturals per aconseguir una edificació compatible amb el medi ambient.

Paraules clau: Àrees edificades, Parc Natural de Cadí-Moixeró, Parc Natural de Comana, Naturbanització, Valor paisatgístic, Barcelona, Bucarest.

\section{Introduction and objectives}

The study compared the process of naturbanization generated in and around two Natural Parks of Southern Europe, which are attractive especially for the urban population of Barcelona and Bucharest. Naturbanization is a concept that identifies, describes and analyses the existence of urbanization processes related to protected natural areas (PNAs) where landscape quality is the specific attraction (Prados, 2009). Naturbanization processes arise from the desire to live in a high-quality natural environment and often include the start-up of enterprises based on either new or traditional economic activities related to an area's cultural and natural heritage. An important indicator is the recovery of population or a slowing of population exodus (Prados 2009). The Barcelona Metropolitan Region (BMR) has experienced constant economic growth since the 1960s, while Bucharest had a planned economy until the 1990s, when its economic base completely changed. Both metropolitan areas play key roles in their geographic contexts.

Preservation of PNAs began as a measure to protect plant and animal species and the geoforms found mainly in National Parks. Other PNAs with particular and singular ecological interest were declared Natural Parks as a way to protect their ecological attributes from tourism impacts (Chape et al. 2008). These protected territories with special landscape qualities have progressively attracted not only hikers and mountain climbers but also a seasonal population and, later on, new permanent residents. Environmental issues have progressively become more important at many levels, being reflected in increased government regulation and population awareness coupled with responsible habits like waste reduction and recycling, use of biodegradable materials, replacement of fossil fuels with renewable energies, and a massive increase in local and ecological food consumption. Land use regulation has increased both the number and size of the PNAs in recent decades, which has brought new challenges for the management boards of PNAs. The beauty of the pristine landscapes that these areas preserve has been highly valued, resulting in the intensification of the functions and services of the parks, including the delivery of educational services, scientific research and dissemination, and the organization and promotion of leisure activities. This activity is a consequence of the increasing interest in nature values but is also very much influenced by other factors, like the rising tourism flows, which interrelate with improved communications and the need to develop post-productive economic activities, particularly in rural natural areas. Therefore, environmental qualities and natural heritage have become commodities that replace the agricultural economic base, clearly in recession, with a service economy that puts urban pressure onto these rural natural areas. Hence, there are two main forces to reconcile: the desire of an increasing part of the population to live close to PNAs, a positive factor in many ways, and the huge governance challenge of integrating the potential of the diverse or even opposing interests in land use.

Within this framework, we analysed the process of naturbanization, comparing two South European PNA to identify those elements that constitute their common trends and then to characterize the changing elements through time and space. The comparative factors chosen for analysis are based on the availability of quantitative data (demographic and housing changes) in both impact areas. This was complemented with the information obtained from structured interviews with principal local actors related with naturbanization processes. 
The paper has 5 sections. Section 2 presents the conceptual framework, centred in naturbanization research related to counterurbanization studies. Section 3 explains the research methods used and briefly describes the characteristics of the case studies (Cadí-Moixeró and Comana). Sections 4 analyses the breadth of naturbanization process in the two PNAs by comparative analysis regarding the evolution of population, the number of tourists and built-up areas in the study areas, and by interpretation of results obtained from the application of interviews. Finally, section 5 presents the conclusions of the present study.

\section{Conceptual framework}

In the frame of the intensification of urban-rural dynamics in the so-called post-productive context, migration to rural areas exerts a fundamental element of analysis to understand the profound transformations taking place in rural areas in general, and in and around PNAs in particular. Indeed, urban deconcentration and increasing environmental awareness both define and express the reshaping of the structure of rural systems in recent decades and reveal the impacts of the change processes taking place (Tulla 2009; Pallarès-Blanch 2012). The main background factors in this context of analysis are public investments in rural areas (Ventura et al. 2010), an increased standard of living (Bosworth 2010), tourism expansion (Gosnell \& Abrams 2011), an improved image of rurality (Halfacree 2012) and the abovementioned environmental awareness (lanoș 2010).

Naturbanization studies analyse the processes that occur when the attractiveness of PNAs turns into the desire to not only visit but to live near these places (Prados 2009; Prados \& del Valle 2010). Naturbanization is among the set of concepts that attempt to define urban deconcentration processes such as core-periphery migration, dispersal, resurgence, population turnaround, turnaround migration, population reversal, rural renaissance, urban exodus, etc. (Solana 2010). All of these terms are derived from the original concept of counterurbanization proposed by Champion (1989) and built on Berry's thesis (1976) presenting this concept as the antithesis of urbanization by confronting concentration and deconcentration population processes.

The counterurbanization phenomenon, initially studied in England, grew during the second half of $20^{\text {th }}$ century across Western Europe, and later on South and Eastern Europe, necessarily adopting different forms and intensities throughout these regions (Mitchell 2004). At the beginning of the $21^{\text {st }}$ century, we found ourselves in a new era in which naturbanization meant migration from the city to rural areas with greater environmental and landscape quality -and vulnerability.

Initial research on naturbanization based in Great Britain, the Netherlands and Spain (Elbersen 2001 ; 2005) concluded that the process was less present in Spain than in North Europe, although it was increasing, particularly in coastal areas like Doñana National Park. Later, Prados (2009) provided a sample of naturbanization processes taking place across South and East Europe, including PNAs close to large metropolitan areas such as Kampinoski National Park in Poland, in mountain areas such as Peneda-Gêres National Park in Portugal, on the Italian island of Sardinia, and Spain's National Parks in the Sierra Nevada of Andalusia and in the Catalan Pyrenees. The common patterns identified in that compilation of naturbanization cases were a) demographic growth; b) positive net migration c) rejuvenation of the population structure and d) a greater presence of women and children and active working population in the demographic composition. Improvements in public services and facilities also were key in favouring accessibility (Prados 2009). At the same time, new means of land pressure due to human actions arrived in these areas where the priority is the preservation of the landscape and environmental values.

Previous studies comparing naturbanization processes in the Catalan Pyrenees and in Sierra Nevada in Andalusia (Pallarès-Blanch 2014) identified population growth resulting from positive net migration and housing expansion in both areas; the growth of second homes was higher in municipalities with PNAs than in the remaining areas. The second-home phenomenon was greater in the Pyrenees but slowed after the first decade of the $21^{\text {st }}$ century; in contrast, the later growth in second homes in Sierra Nevada led to a higher recent growth rate. Regarding the impact on sustainable local development provided by the naturbanization process taking place, the results show the positive influence of the PNAs in the model of local development, although 
this was more evident in the case of Andalusia due to greater investment and the public policies involved, like EU funds (Pallarès-Blanch 2014).

The process of economic restructuring that began in the 1960s in Southern European countries, when the rural population migrated to the urban industrial areas, was consolidated with the effects of marketplace globalization at the end of the 1980s, having a negative effect on traditional agrarian activities (Paniagua 2002). The results of this rural restructuring differed between those rural spaces with large, competitive operations specialized in the food processing sector and those of smaller size and profitability, frequently located in mountain areas and therefore having to diversify their economy, orienting it towards activities compatible with the preservation of highquality natural spaces (Woods 2011). Thus, the economic and social context that gave rise to naturbanization, in contrast with counterurbanization, corresponds to a differentiation between the rural world as an agricultural market economy competing at global scale and a multifunctional rural world where the economy is based on the combination of diverse value-added and highquality activities that are appreciated by a nearby urban population (Marsden, 2003; Woods 2011). Nonetheless, the principal characteristic of the intensification of the urban-rural dynamic is the conversion of the countryside into a commodification of the rural (Best 1989; Cloke 1993) for which there is demand not only for tourism but also for quality agricultural products (local foods and other crafts).

In many rural areas, and particularly in mountainous zones or in wetlands, often with PNAs, agricultural and food production have been gradually transforming their traditional secondary role in the market, towards a more strategic role in the agrofood web domains by developing proximity networks of production and distribution (Morris 2011). Therefore, value-added is the key to success for the farms that have persisted as well as for those new enterprises established in or around the PNA and based on the production, preparation and distribution of high-quality, often organic, foods and craft goods and services. This quality is often labelled by EU schemes of geographical indications and traditional specialities. The value-added goods are taking advantage of what these areas have in synchrony with the context of these rural mountain areas (PallarèsBlanch 2012). Despite efforts to achieve a viable organization, these natural-rural areas face important challenges in preserving their original economic, social and territorial advantages. The various levels of governance prioritize a sectoral perspective in resolving the problem of rural spaces, but with little success. There is a need to return to more cross-cutting policies to meet the current needs of these most marginalized types of multi-sector territories (Domínguez Garcia 2012).

In this whole picture, studies on naturbanization processes provide a framework of analysis by which to examine emerging demographic, economic and spatial trends in areas with significant PNAs, helping us to understand the rationale and values of these new migration patterns and their effects on the destination areas.

The current demand for a natural environment provides a great opportunity to revitalise rural natural areas that lost ground, and the demographic and economic recovery, the stimulation of rural multifunctionality and the creation of new job opportunities are among the benefits of immigration to rural areas (Baumgartner 2013). The creation of eco-economic strategies (Horlings 2014) linked to rural tourism (Haugen 2008; Lordkipanidze 2005) or to new services related to nature conservation (Andersson 2009), known as green entrepreneurs (Schaper 2005) or ecoentrepreneurs (Volery 2002), are even more reasons to presume that naturbanization can promote environmentally friendly built-up areas. Among the positive aspects of naturbanization, we can identify the following elements: (a) there is a seasonal or permanent migration halting the population loss or even spurring population recovery; (b) the new settlers consider the environmental quality and heritage to be one of the motivations for their move and they favour its preservation; (c) trends toward permanent residences promote new activities and strengthen the most value-added traditional activities; and (d) intensifying the interaction between urban and rural cultures enhances local social cohesion (Shucksmith 2009; Norris 2010; Gosnell 2011; Morris 2011; Pallarès-Blanch 2015b).

However, naturbanization could be pernicious if it harmed and degraded the natural values that have been preserved for decades. In mountainous areas like the Pyrenees, some of the downhill 
skiing resorts became crowded with second residences because the model of development (now in recession) was highly based on speculation in real estate and the housing bubble (Norris 2010). In other natural areas closer to big cities, second residences may not be as prominent, but these areas face higher flows of day visitors that increase the demand for leisure and personal services.

Economic and local development perspectives were key in areas were naturbanization provided benefits. Nevertheless, in other areas the naturbanization process was giving rise to new conflicts, constraints and pressures on the territory and the local community. In these zones, the increased number of housing units reduced landscape quality (Pallares-Blanch 2014) and increased the risks to its conservation in wild-urban interface zones (Badia 2010). Therefore, to maintain environmentally friendly built-up areas, it is important to relate the popular notion of rurality (peace, tranquillity, low population density, strong community relationships, etc.) to the value placed on the natural environment and cultural heritage (Paniagua 2008), a situation that can be found in a PNA. If we also consider the processes of rural development that propose the preservation of heritage and the recovery of some traditional agrarian methods, combined with the incorporation of new ones related to new technologies (T\&IS) ${ }^{5}$, we are led to embrace the concept of natural parks that incorporate economic and social development, along with the maintenance of the natural and cultural heritage, with a focus on sustainability (PallarèsBlanch 2015b).

Naturbanization can also be understood from the perspective of the conceptual triad of rurality suggested by Keith Halfacree (2007) as simultaneously a material fact, an image, and a way of life. The conceptual triad is based on the three-fold approach offered by Henri Lefebvre (1991) to explain the complexity of the rural space, which highlights three ways (physical, mental and social) to approach the meaning of space, while stressing the unity between them, thereby understanding space as perceived, conceived and lived. The first of the three notions takes the physical and tangible form of space, the second notion indicates the mental construct of space, basically through rational knowledge, and the third sees in the same space the experience that provides other forms of knowledge, awash with symbolism and emotional meaning (Elden 2004). Going back to Halfacree's idea of rurality being simultaneously a material fact, an image and a way of life, we see how rural localities have relatively distinctive practices related to production and consumption that offer ways of formally representing that which is rural and reflect the individual and collective experience of everyday life in the countryside. These three conceptions of rurality are not necessarily convivial and certain tensions may exist, so that when the material reality that is represented and that which is experienced do not coincide, this results in an incongruent and poorly unified reality.

Within naturbanization, we can identify this conceptual triad in individual choices for housing migration to areas near a PNA. Ideally, recent arrivals or those who have returned to these rural areas have three basic longings: (a) they want to live, work, and shop in the countryside; (b) they hold an image of a quality of landscape that they want to enjoy and, at the same time, preserve; and (c) they attempt to become involved in the daily local life through cultural events and various local organizational structures (Pallarès-Blanch 2015a). Without a doubt, imperfect situations within this model can be explained by the absence of one of these three basic characteristics. Some tourists, with or without a second residence, do not attempt to become involved in rural life and some have no interest in the area's production economy. However, if the quality of the landscape is well preserved it will remain as a healthy sign of the physical element, which will socially generate a landscape culture that in turn can be transferred into good practices. Vigilance about landscape conservation should be better integrated into PNA management and sectorial policies such as housing, citizen services, culture and local development. In other words, in the context of increasing intensification of land uses, PNAs may not be sufficient to accomplish their role of protecting biodiversity (Gurrutxaga 2009; Calvache 2016). There is the need, therefore, to set aside the traditional static approach applied to PNAs management focused on features rather than dynamic processes that are behind the functioning of ecosystems (Crofts 2004). This is particularly meaningful in Mediterranean regions, characterized by a rich

\footnotetext{
${ }^{5}$ Technologies and Information Systems
} 
biodiversity, where preservation of landscape is associated with semi-natural habitats (Marull 2010).

\section{Methodology and study areas}

\subsection{Research methods}

The methods designed to test the existence of a naturbanization process in two distinct areas, combine quantitative and qualitative tools. In the first stage, we analysed and compared the main elements of each of the two protected areas based on available documents such as management plans, local strategies, reports of projects, national legislation, etc. At the same time, we did research in specialized literature for the identification of studies which focused on the two areas.

The breadth of naturbanization process was evaluated based on statistic data regarding the population and the number of houses. We also took into account data regarding the number of tourists. The information obtained for each of the two protected areas and statistic data was permanently compared for the identification of common points and differences. But the statistical data only allow the realization of an overview, because we could not identify the existing characteristics at village level and some information are unavailable (such as the number of secondary homes for Comana). In addition, speaking of protected areas, certain conservation rules must be observed in them, the local actors (representatives of administrations of parks and local authorities) influence or even coordinate the carrying out of activities at local level.

Therefore, in order to identify the impact of naturbanization process at local level, structured interviews inside and around each natural park were conducted with 30 individuals $(n=60)$ to collect qualitative data and opinions. In it, we pursued two main directions: a) the individual motivations of those who moved (including permanent or seasonal housing); and b) how this area transformed in the last years under the impact of newcomers, with highlight of advantages and current disadvantages, identification of new economic activities, characteristics of local community, lifestyle, etc. In this respect, the interview was composed of 25 questions organized in four sections:

(i) Migration process: personal history of living, the main motivations to reside or spend time in these areas, accessibility degree;

(ii) Local characteristics/resources and the new economic activities which can contribute to rural development and the origin of investors;

(iii) Local community and rural culture: degree of integration of newcomers, conflicts, attitudes, culture, contribution to the local sustainable development through consumption habits, the way of life in the area, etc.

(iv) Description of the personal profile, including age, gender, origin, lifecycle period, work (commuting, telecommuting, retired, unemployed), and type of household;

The interviews were addressed to a previously designed sample of profiles, in order to register the opinion of all the categories of local actors, organized in five groups:

(a) Socioterritorial role, divided into five categories: park managers and employers (PkMang); members of local administration who work in diverse activities (LocAdm); technicians and professionals who live and work in the area (TecResch); other permanent residents working in other professions (PermResid); and seasonal residents in second residences (TempResid).

(b) Situation with respect to mobility or migration: Native-born individuals who have almost always lived in the area (Local); Native-born individuals who left the area to study or work and have returned (LocReturn); Residents who immigrated from urban areas for employment reasons or for a lifestyle change (UrbMigrat); Residents who have arrived, either directly or via urban areas, from other countries (Foreign UM); and seasonal residents who have second residences or stay in the area's hotels (SecHomes). 
(c) Geographic distribution: Where diverse geographic zones exist, as in the case of CadíMoixeró NP, an effort was made to distribute interviews to represent the different settings (Alt Urgell, Berguedà, and Cerdanya), referred to as districts (comarques, or counties). In Comana NP, they were distributed in several villages across two communes (Călugăreni and Comana) considered the most representative areas.

(d) Gender distribution: An attempt was made to distribute interviews fairly, in accordance with the population distribution.

(e) Age distribution: Four age groups were established and considered when selecting persons to interview: younger than 20 years, 20-40 years, 40-60 years, and older than 60 years. Special attention was given to the two middle-aged groups, which people tend to be most active in the workforce and community.

The results obtained from the application of the 30 interviews in each of the two natural parks were compared and analysed by statistical analysis.

\subsection{Two Southern Europe Metropolitan areas}

The Barcelona Metropolitan Region (BMR) has more than 5 million inhabitants in 3,236 km², a population density that exceeded $1,500 \mathrm{inhab} / \mathrm{km}^{2}$ in 2011 . It is the most populated region in Catalonia, which has 7.5 million inhabitants. The Bucharest Metropolitan Area (BMA) has over 2.4 million inhabitants in $4,392.5 \mathrm{~km}^{2}$, a population density of 555.9 inhab. $/ \mathrm{km}^{2}$ in 2011 . Bucharest is the capital of Romania (>20 million inhabitants). Economic development in the BMR has been greater than that of the BMA for many years. In the province of Barcelona, the GDP increased from 19,000 euros per inhabitant at market prices in 2000 to 26,500 in 2011; in contrast, GDP increased from 4,000 to 15,500 for the same period in Bucharest-Ilfov. By way of comparison, the EU-28 increased from 19,000 euros to 25,100 euros, Spain from 15,600 to 22,700, and Romania from 1,800 to 6,200, respectively (Eurostat).

\subsubsection{The Barcelona Metropolitan Region}

The BMR (Figure 1) constitutes one of the seven functional areas of the General Territorial Plan for Catalonia (1995) ${ }^{6}$. BMR population has increased steadily for the last 30 years and the growth increases between 2001 and 2011 were due to massive immigration rates $(1.7 \%$ annual increase because of foreign migration and 0.2 because of natural growth in this period ${ }^{7}$ ), which, in turn, reflects the economic growth of the region.

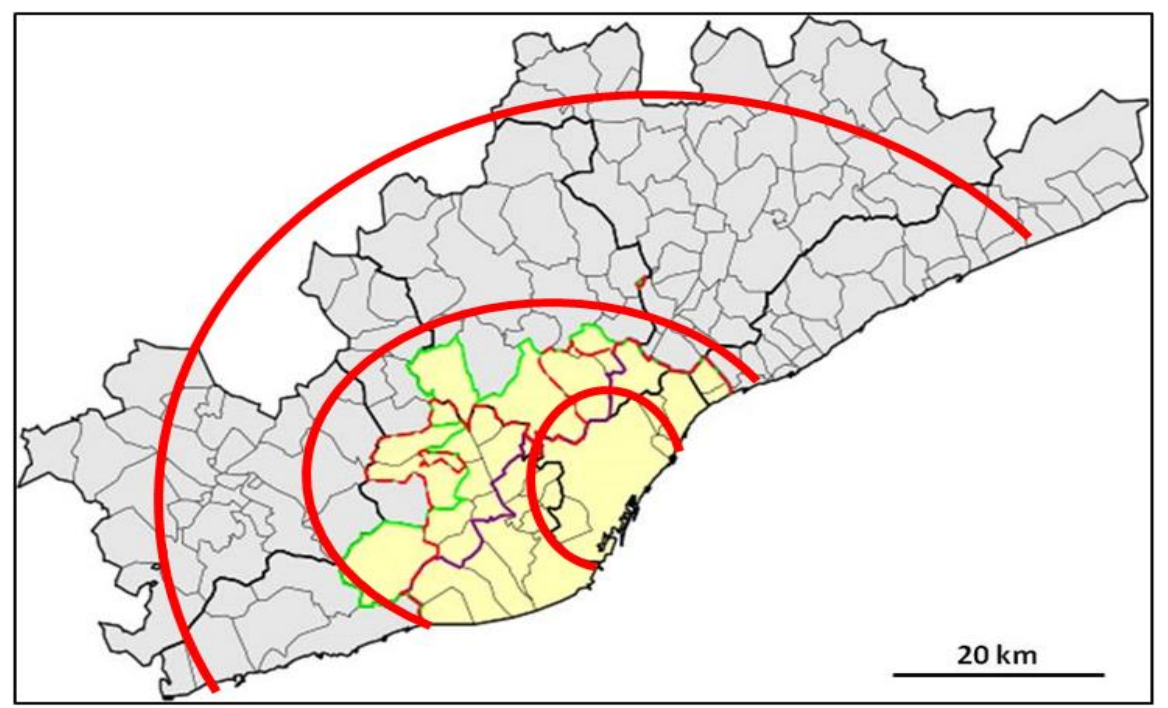

Fig 1. Municipalities of Barcelona Metropolitan Region. Zone limits in red lines. Source: Entitat Municipal Metropolitana de Barcelona

\footnotetext{
${ }^{6}$ Law 1/1995, 16 March, Pla Territorial General de Catalonia, approved by the Parlament of Catalonia.

7 Data from "Censos, Padrones y Movimiento Natural de la Población” INE 2015, elaborated by CED.
} 
Barcelona city $\left(101 \mathrm{~km}^{2}\right)$; the centre of the BMR, lost population from $1,754,900$ in 1981 to 1,615,448 in 2011 (Table 1). Ring 1, with 33 municipalities $\left(532 \mathrm{~km}^{2}\right)$ and extending $25 \mathrm{~km}$ from the centre of Barcelona city, has increased its total residents thanks to immigration, and maintained its $31.9 \%$ quota of the total population. Ring 2, with 72 municipalities and $1.362 \mathrm{~km}^{2}$, located from 25 to $50 \mathrm{~km}$ from the centre of Barcelona, experienced the strongest population growth, from 1,123,814 (25.7\%) in 1981 to $1,615,311$ (32\%) in 2011.

Tab 1. Population of the Barcelona Metropolitan Region $\left(3,236 \mathrm{~km}^{2}\right)$ and its zones. Source: Idescat, Generalitat de Catalonia

\begin{tabular}{|r|r|r|r|r|r|r|}
\hline Year & $\begin{array}{c}\text { Population } \\
\text { BMR }\end{array}$ & Inhab./km² & $\begin{array}{c}\text { \% quota } \\
\text { BCN/Total BMR }\end{array}$ & \% Ring 1 & \% Ring 2 & \% Ring 3 \\
\hline 1981 & $4,372,854$ & 1351.3 & 39.9 & 31.9 & 25.7 & 2.5 \\
\hline 1991 & $4,411,200$ & 1363.2 & 38.1 & 31.8 & 27.4 & 2.7 \\
\hline 2001 & $4,579,560$ & 1415.2 & 32.9 & 31.5 & 31.9 & 3.7 \\
\hline 2011 & $5,023,161$ & 1552.3 & 32.1 & 31.9 & 32.0 & 3.9 \\
\hline
\end{tabular}

Finally, BMR Ring 3, more than $50 \mathrm{~km}$ away from Barcelona, has gained population share, from $2.5 \%(109,311$ inhabitants) to $3.9 \%$, although this ring has a large population (181,506 inhabitants) (Nel-lo 2001; Muñoz 2011). The BMR growth process, together with the displacement of the population from the centre to the periphery, responds to three main factors. Initially, the motivation for the deconcentration was to find lower housing and land prices (Muñoz 2007). The second factor is to be found in the relatively good transportation infrastructure, since public transportation by rail, subways, and intercity bus service has improved over the years. This is particularly so in Ring 1 , where $60 \%$ use public transit and $40 \%$ private vehicles. Nonetheless, more than $60 \%$ of those traveling to Ring 2 and Ring 3 drive private vehicles, using the highway and tollway systems. The third factor that explains deconcentration of urban population from the centre of the city is the wish to exchange the polluted and stressful big city for an atmosphere closer to a local community lifestyle, living if possible in a semi-detached house with garden. Since the economic crisis began in 2008, the increasing cost of services in dispersed developments have slowed this urban sprawl trend, evidencing a rebirth of the compact city (Nel·lo 2011).

\subsubsection{Bucharest Metropolitan Area}

Bucharest is the most important polarizing centre of Romania, but on the administrative level, there is no integrated development plan for it and the surrounding communes and towns (Popescu, 2012; Tălângă et al. 2011).

In Romania, the metropolitan area is defined as being "constituted through association, based on voluntary partnership, between the major urban areas and the urban or rural settlements located in the close neighbouring areas" (Romanian Law 351/2001). Locally, the administrations show reticence about being included in any form of association with the capital city that could decrease their autonomy. One of the most recent approaches to defining the BMA, carried out within the Espon GROSEE Project (2013), highlights the metropolitan area using several sets of indicators (lanoș, 2014). Thus constituted, the BMA contains territorial-administrative units from 5 counties (Ilfov, lalomița, Călărași, Giurgiu, Dâmbovița), plus Bucharest (Figure 2), having a surface of $4,392.50 \mathrm{~km}^{2}$.

In 2011, the BMA population was $2,440,000$, of which $77 \%$ lived in the Bucharest municipality (Table 2). A population decrease (6\%) was recorded from 1992 to 2011, with two separate intervals: a demographic decrease (1992-2002), followed by a slight increase in 2011. This situation was influenced by several factors, including the following:

a) Changing demographic behaviour of the population after 1990, which led to a decreased birth rate, increased death rate, and a process of population ageing (in some areas);

b) Migrating fluxes within the study area, from Bucharest to the adjacent area;

c) Scant compliance with statistical recording requirements. 


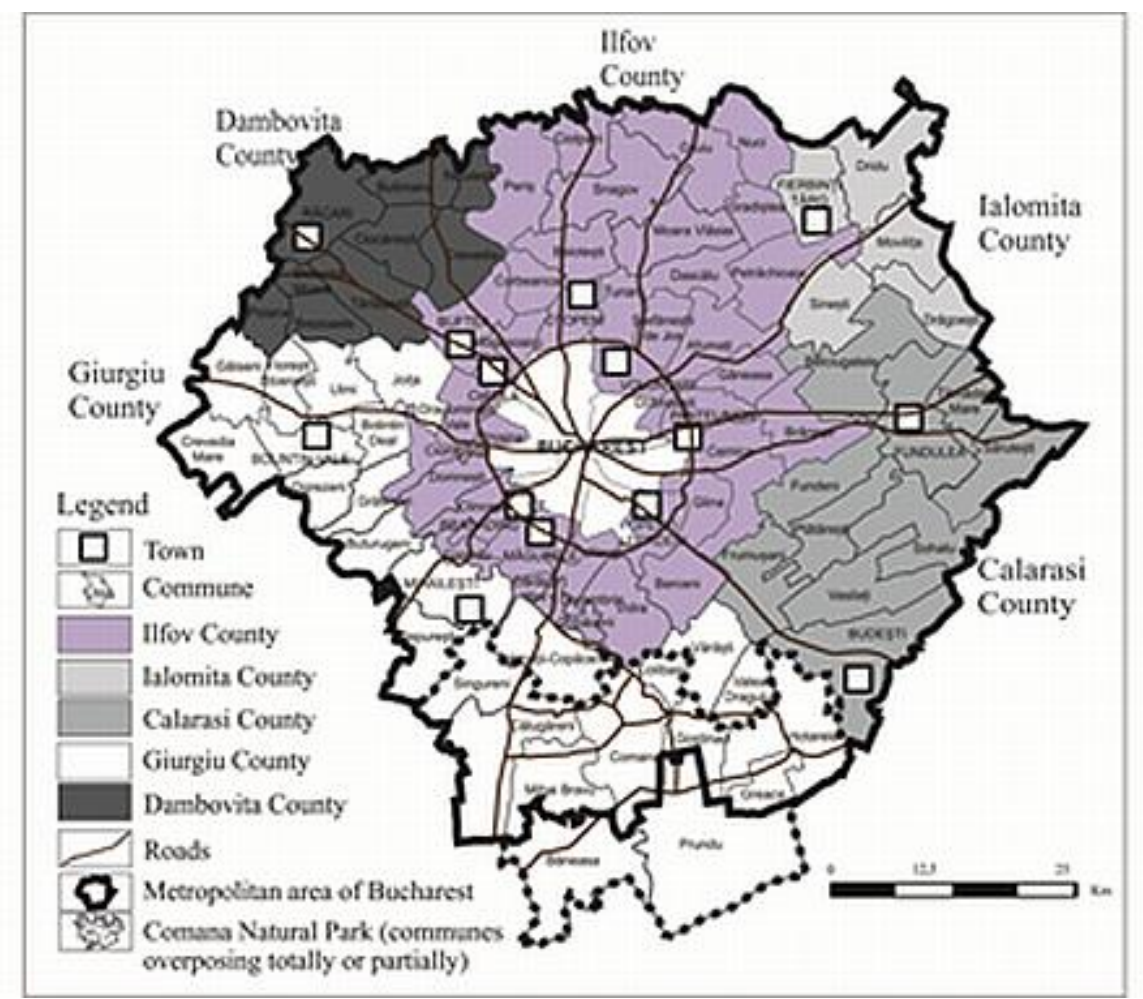

Fig 2. Administrative-territorial units of BMA and Comana NP.

Tab 2. Population, surface area, and density in Bucharest Metropolitan Area (1992-2011). Source: National Institute of Statistics, census data

\begin{tabular}{|c|c|c|c|c|c|c|}
\hline \multicolumn{5}{|c|}{ Surface $\left(\mathrm{km}^{2}\right): 4,392.50(\mathrm{BMA})=237.87$ (Bucharest) $+4,154.60$ (Adjacent area) } \\
\hline Year & \multicolumn{3}{|c|}{ Population } & \multicolumn{3}{c|}{ Density (people/km²) } \\
\hline & BMA & Bucharest & Adjacent area & BMA & Bucharest & Adjacent area \\
\hline 1992 & $2,589,153$ & $2,06,7545$ & 521,608 & 589.4 & $8,691.9$ & 125.5 \\
\hline 2002 & $2,433,158$ & $1,926,334$ & 506,824 & 553.9 & $8,098.3$ & 122.0 \\
\hline 2011 & $2,441,772$ & $1,883,425$ & 558,347 & 555.9 & $7,917.9$ & 134.4 \\
\hline
\end{tabular}

Analysis comparing the capital city to the adjacent area showed that Bucharest continues a decreasing trend. In the rest of the area, a decrease was observed in the first interval, followed by an increase in the number of inhabitants due to the positive net migration rate.

Significant differences were observed in the interior of the metropolitan area. The population increased by more than $15 \%$ in the territorial-administrative units located near the capital city, mostly on the northern and eastern sides. The process of urban expansion was influenced by the underdeveloped physical infrastructure, with an undersized road network. Therefore, the majority of those who choose to live outside Bucharest build houses closer to the city. Additionally, the public transport is deficient, and the means of transport are insufficient and crowded during the peak hours.

\subsection{Case studies: The Natural Parks}

Cadí-Moixeró Natural Park $(C-M N P)$ is located in the Pyrenees, being the closest alpine park to metropolitan area of Barcelona, with a travel time of one hour and a half to almost 3 hours (130$180 \mathrm{~km}$ ), Figure 3. With improvements to the highway systems, new communications technologies have brought the central urban areas closer to the periphery, facilitating seasonal mobility and permanent migration to the PNA and their surroundings. 


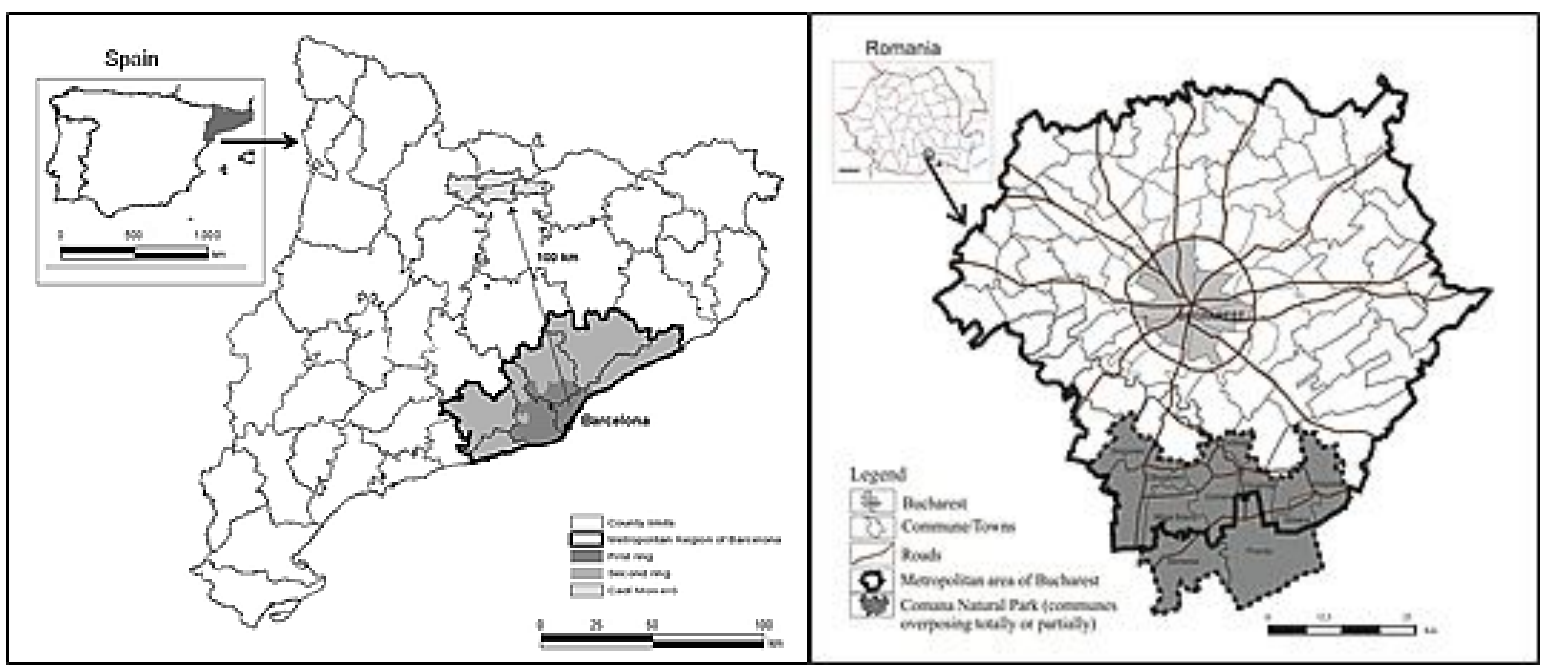

Fig 3. Geographical location of Cadí-Moixero and Comana Natural Parks. Source: own elaboration from data provided by ICGC and Comana Natural Park

Comana Natural Park (CNP) is located in a plain area, with a distance of $30-50 \mathrm{~km}$ away from Bucharest, Figure 3. The urban population was attracted by forest areas, rivers and lakes (lanoș, 2010), wishing to live in the vicinity of those areas. The selection of this case study was because it is the only natural park in the vicinity of Bucharest, which presents rural characteristics. Generally, the Southern area of Bucharest metropolitan area was less attractive, but a reorientation in that direction has recently been noted (Pătroescu 2011). The travel time to this city is approximately 40-60 minutes from Bucharest downtown.

\subsubsection{Cadí-Moixeró Natural Park}

The C-M NP, established in 1983, occupies 41,060 ha distributed across three districts: Alt Urgell, Berguedà, Cerdanya (Figure 4). On a European level, in 1987, the Natural Park was declared a SPA (Special Protection Area) for birds, in accordance with European Council Directive 79/409/EEC. In 2003, via a Commission Decision, the inclusion of the Natural Park as part of the Alpine region of the Natura 2000 Network was approved because it has more habitats and species of flora and fauna of Community Interest - as defined by the EU's Habitat Directory than any other Catalan protected area. The ecological quality and singularity of the range is fully recognized (Figure 5). The altitudes range from $800 \mathrm{~m}$ at the valley floors to 2,648 $\mathrm{m}$ at the highest peak. The range extends more than $30 \mathrm{~km}$ and constitutes a challenging barrier to cross. The boundaries of the park involve 17 municipalities with an area of $410.6 \mathrm{~km}^{2}$ belonging to the NPA.

For preserving the natural ecosystems and all their elements, they have implemented more programs, such as the Plan to Improve the Landscape, Plan for the Prevention and Extinction of Forest Fires, or the recovery of orchards and their exploitation. Financing these initiatives is complex because, in addition to funds from the Generalitat de Catalonia (60\%), there are agreements with the local governments, public and private associations, and especially with 'La Caixa', a Catalan banking entity that funds many social programs. There are difficulties in the coordination of objectives of local administration and park authorities. 


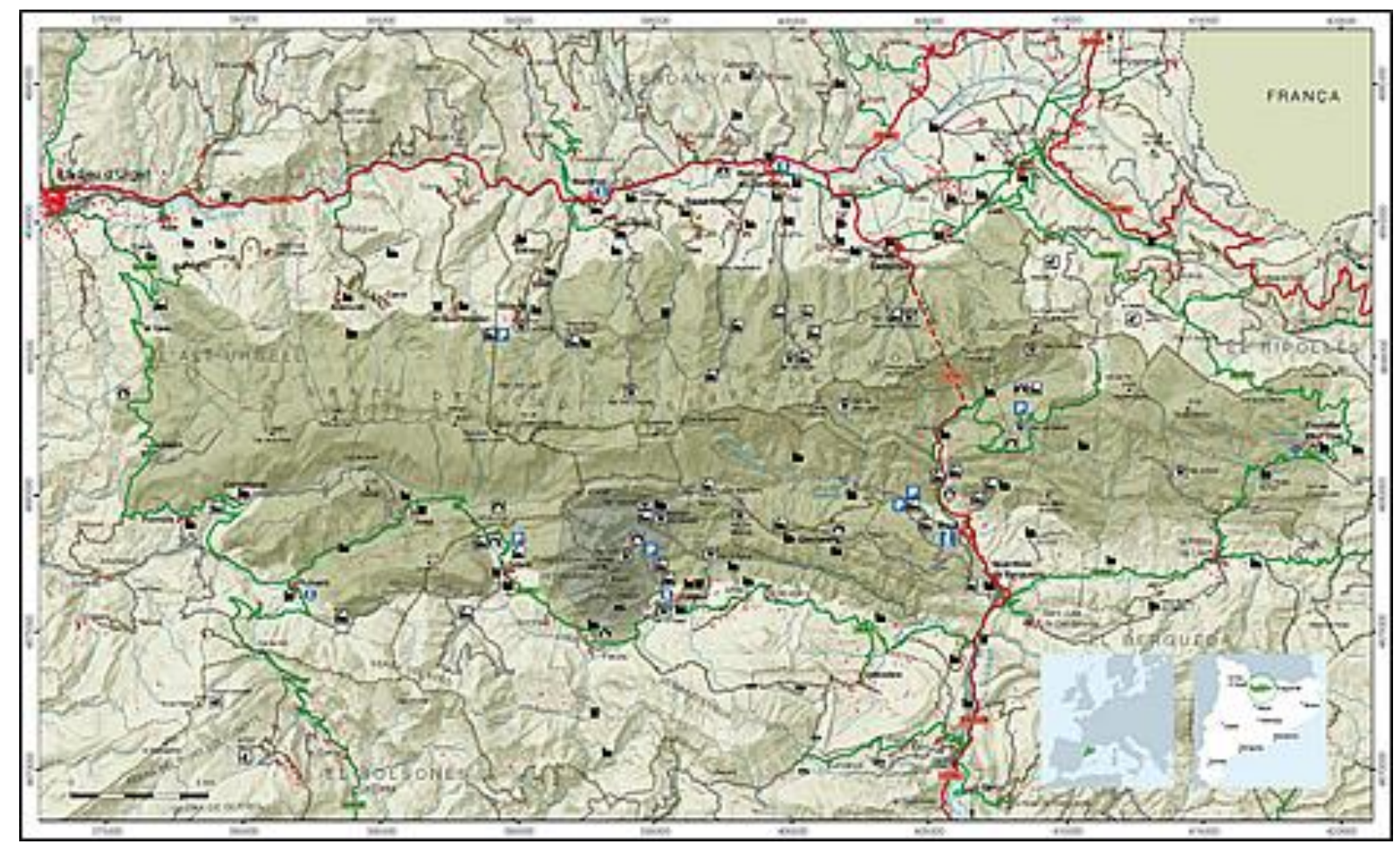

Fig 4. Cadí-Moixeró NP. Source: Processed from the Administration of this Park
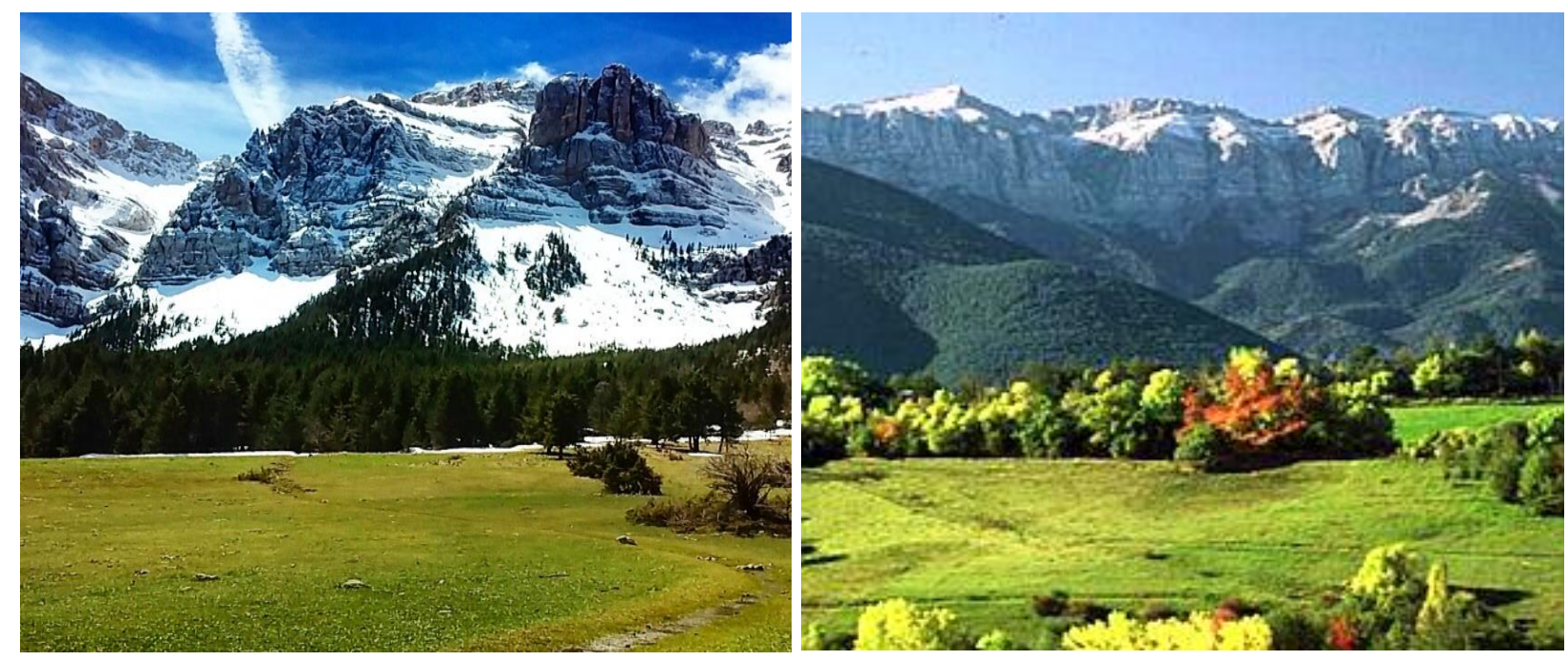

Fig 5. Cadí-Moixeró NP landscape. Source: Antoni F. Tulla (2016) 


\subsubsection{Comana Natural Park (Romania)}

CNP was designated a protected area of national interest in 2004, with a surface of over 24,963 hectares. The area was included in the Nature 2000 network and since 2011, it has been considered a wetland of international importance, the Ramsar Site (Figure 6).

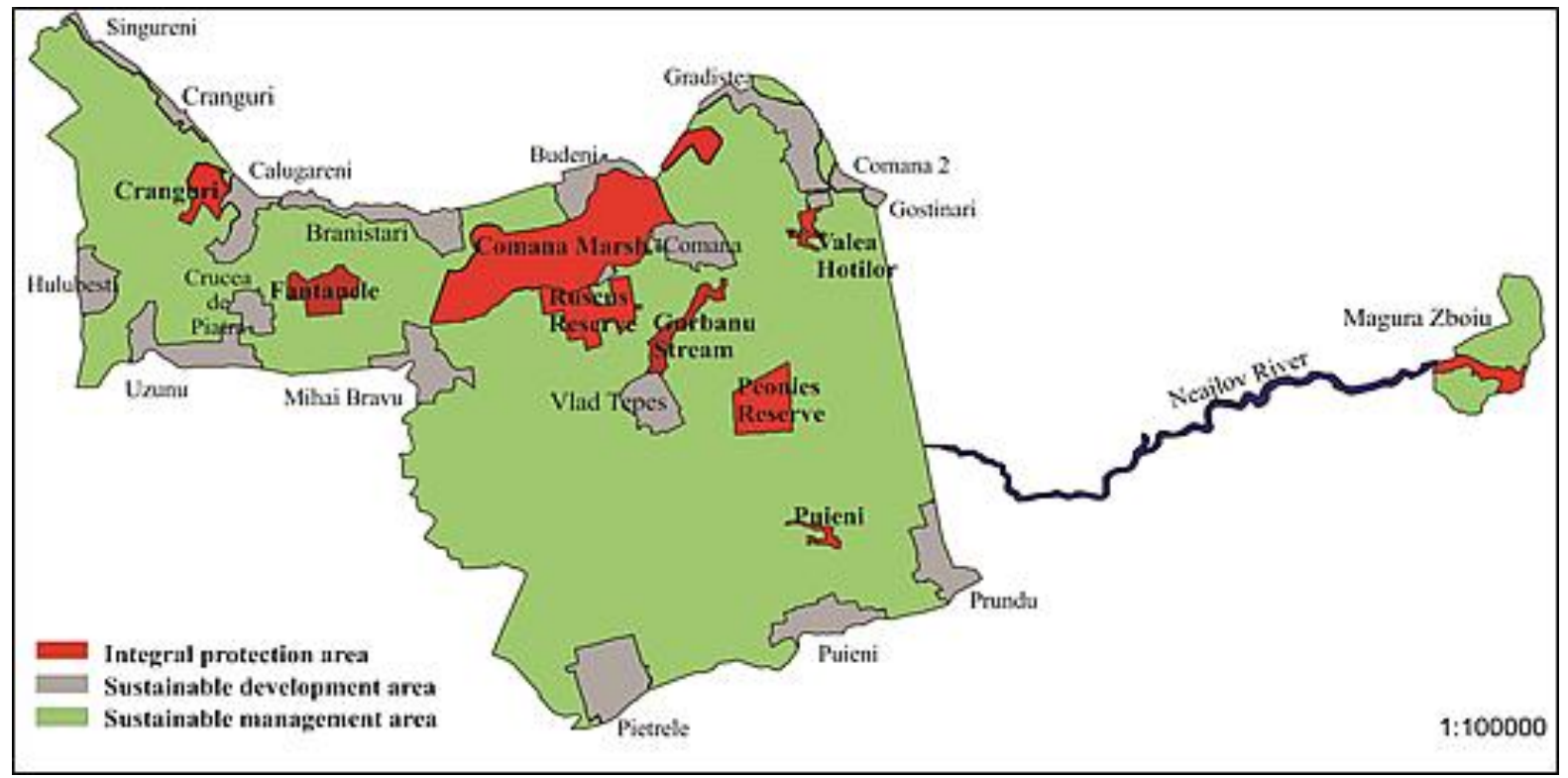

Fig 6. Internal division of the Comana Nature Park. Source: adapted from Comana Natural Park Administration materials

The surface area of the park is split into three distinct areas in keeping with the Management Plan of the CNP: integral protection area (9.3\%), sustainable management $(75.1 \%)$ and sustainable development (15.6\%). The most important protected natural area is Comana Marsh (1206.4 ha), Romania's third largest wetland and the second in biodiversity (Management Plan of the CNP, 2013) (Figure 7). More than 1300 species of plants, 10 species of amphibians, 9 species of reptiles, 30 species of fishes, and 157 species of birds have been identified within the park (Visiting Strategy of the CNP, 2011).

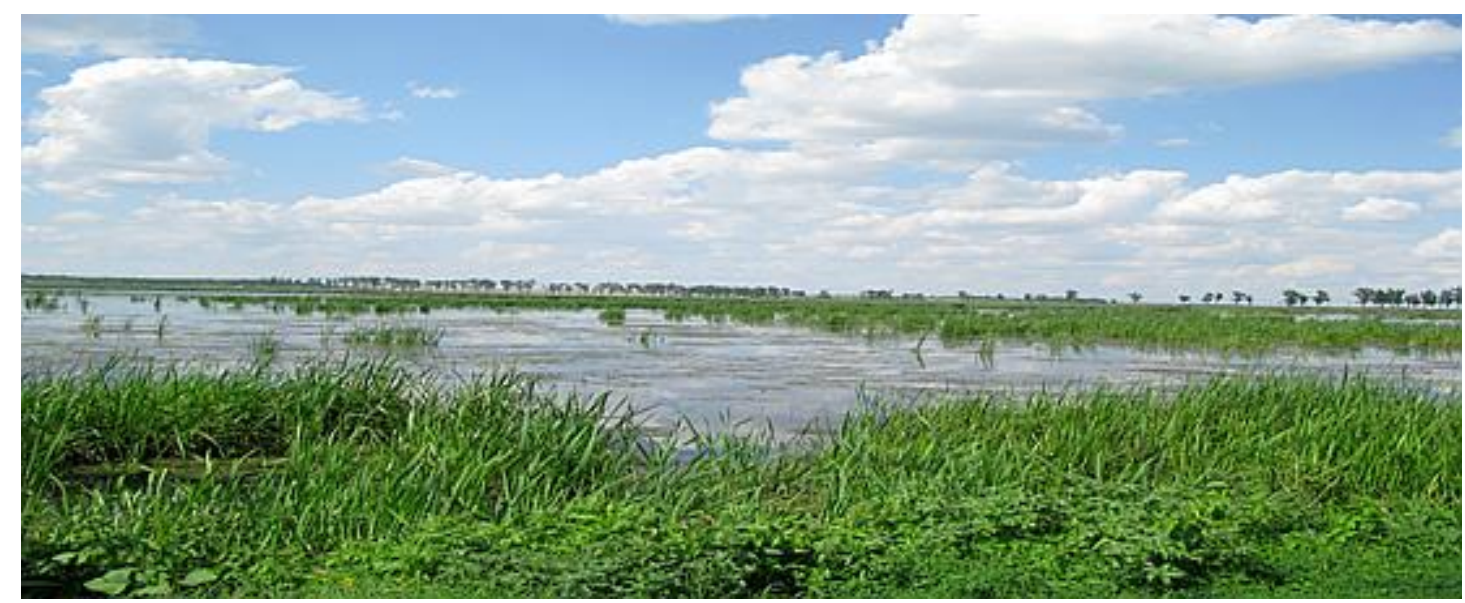

Fig 7. Comana marsh. Source: I.V. Stoica (2014)

The landscape in this area is diversified, with rural settlements, roads, agricultural lands (61.8\%), forestry heritage (32.1\%), Comana marsh (4.8\%), and swampy wetlands and saltwater pasture lands, periodically liable to flooding or standing water (1.2\%) (Comana Natural Park Administration).

Over the last few years, ecological reconstruction of Comana marsh activities have been undertaken. The project completed construction of a pavilion for information and monitoring; 
a short dike to dam water; installations specific to lakeside activities, including pedestrian walkways, docks and signalling indicators; and birdwatching towers for ornithologists. In addition, staff initiated public awareness and information activities (Peicea 2013a, Peicea 2013b, McConville 2014).

This area also contains an important anthropic objective, a cultural heritage site, the Comana Monastery, built in 1588 and restored in 1700; it was originally built onto the ruins of a monastery founded by Vlad Tepes in 1461, also known by the pseudonym of Dracula (Picu 2011).

The natural park territory is included in 10 administrative-territorial units, but mainly in six communes. More than $60 \%$ of the land is privately owned and the majority of the forestry surfaces are managed by the state. Within the park, there are 16 villages (entirely or partially) belonging to 6 communes, which totalize a population of over 28,000 inhabitants.

Being recently created as a natural park, we can notice difficulties in the observance of environmental protection rules.

\section{Naturbanization in the Cadí-Moixeró and Comana Natural Parks}

For the evaluation of naturbanization process, the general changes produced were analysed in terms of population, houses, tourists in analysed areas and the perception of local actors on the transformations produced and their sustainability.

\subsection{Evolution of population, tourists and number of houses}

Apart from the native population, the analysed areas were selected as residence by newcomers but also by the persons who came back to native villages. A part of them live only temporarily in the newly built houses. To them we can add the tourists who are attracted by certain objectives and activities from the analysed areas.

Evolution of population and tourists. The population of the 17 municipalities that have $C-M N P$ within their boundaries declined greatly from 1981 until 1996, mainly because agricultural activities were abandoned throughout this territory but also because of a mining crisis in the southern tier (Berguedà), with drastic job losses in the lignite and cement industries (PallarèsBarberà 2005). In contrast, in Cerdanya -the part of the territory with the greatest attraction for tourists - there has been a major recovery; accessibility greatly improved with the construction of the 5-km Cadí tunnel, connecting these areas with the BMR, in 1983. In Alt Urgell district, where the agrarian sector has enjoyed better survival through innovative measures, basically focused on the food craft businesses, there was a recovery in 1996, followed by population stability (Pallarès-Blanch 2015a).The three districts with land in the Cadí-Moixeró NP present substantial geographical and socio-economic differences, not only because of the altitude but also in respect to orography. This affects population changes (absolute and relative data) are seen in Table 3 . In this data are included only the municipalities of these three districts which have part of their territory in the park. Population density of this territory is 12.9 inhab. $/ \mathrm{km}^{2}$ in 2011.

Tab 3. Area, altitude, and population (1981-2011), C-M NP main districts. Source: Idescat, Generalitat de Catalonia

\begin{tabular}{|c|c|c|c|c|c|c|c|}
\hline \multirow{2}{*}{ Comarca } & \multirow{2}{*}{$\mathbf{K m}^{\mathbf{2}}$} & \multirow{2}{*}{$(\mathbf{m} / \mathbf{M})^{*}$ metres } & \multicolumn{5}{|c|}{ Population (Inhabitants) } \\
\cline { 4 - 8 } & & $\mathbf{1 9 8 1}$ & $\mathbf{1 9 9 1}$ & $\mathbf{1 9 9 6}$ & $\mathbf{2 0 0 1}$ & $\mathbf{2 0 1 1}$ \\
\hline Alt Urgell & 274.1 & $768 / 1,335$ & 818 & 766 & 785 & 773 & 775 \\
\hline Berguedà & 367.6 & $720 / 1,423$ & 6,218 & 5,878 & 5,454 & 5,202 & 5,445 \\
\hline Cerdanya & 241.7 & $967 / 1,263$ & 3,380 & 3,278 & 3,326 & 3,792 & 5,195 \\
\hline TOTAL & $\mathbf{8 8 3 . 4}$ & $\mathbf{7 2 0 / 1 , 4 2 3}$ & $\mathbf{1 0 , 4 1 0}$ & $\mathbf{9 , 9 2 2}$ & $\mathbf{9 , 5 6 5}$ & $\mathbf{9 , 7 6 7}$ & $\mathbf{1 1 , 4 1 5}$ \\
\hline Population density ( inhab./km2 ) & 11.8 & 11.2 & 10.8 & 11.1 & 12.9 \\
\hline Variat. Index, Alt Urgell: $\boldsymbol{H} 1981=\mathbf{1 0 0}$ & $\mathbf{1 0 0 . 0 0}$ & $\mathbf{9 3 . 6 4}$ & $\mathbf{9 5 . 9 7}$ & $\mathbf{9 4 . 5 0}$ & $\mathbf{9 4 . 7 4}$ \\
\hline Variat. Index, Berguedà: $\boldsymbol{H} 1981=\mathbf{1 0 0}$ & $\mathbf{1 0 0 . 0 0}$ & $\mathbf{9 4 . 5 3}$ & $\mathbf{8 7 . 7 1}$ & $\mathbf{8 3 . 6 6}$ & $\mathbf{8 7 . 5 7}$ \\
\hline Variat. Index, Cerdanya: $\boldsymbol{H} 1981=\mathbf{1 0 0}$ & $\mathbf{1 0 0 . 0 0}$ & $\mathbf{9 6 . 9 8}$ & $\mathbf{9 8 . 4 0}$ & $\mathbf{1 1 2 . 1 9}$ & $\mathbf{1 5 3 . 7 0}$ \\
\hline Variation Index, TOTAL: $\boldsymbol{H} \mathbf{1 9 8 1}=\mathbf{1 0 0}$ & $\mathbf{1 0 0 . 0 0}$ & $\mathbf{9 5 . 3 1}$ & $\mathbf{9 1 . 8 8}$ & $\mathbf{9 3 . 8 2}$ & $\mathbf{1 0 9 . 6 5}$ \\
\hline${ }^{*}$ minimum and Maximum height \\
\hline
\end{tabular}


However, in addition to ecological conservation, protection from tourism impact was another decisive factor to preserve the area, as is recorded in the constitutional law of $1983^{8}$, which gives an idea about the longstanding attractiveness of the park as a tourist destination.

In 2012, the park received 430,000 visitors and 29.80 euros/visitor/day of expenditure, a medium value between the highest ( 59.69 at a coastal park) and the lowest ( 0.78 for the park nearest to BMR) expenditure (Obra Social la Caixa, 2015). This park is close to many with potential visitors living in France and Andorra (Pallarès-Blanch 2013).

In CNP, between 1992 and 2011, the population decreased by approximately $18 \%$, especially in the least accessible locations far from the main access roads. This situation is determined by the increased mortality rate due to the process of demographic ageing, simultaneously with a decrease in birth rate. At the same time, there was a negative net migration rate.

Tab 4. Evolution of population on the communes from CNP (1992-2011). Source: Romanian National Institute of Statistics.

\begin{tabular}{|c|c|c|c|c|c|c|c|}
\hline \multirow{2}{*}{ Commune } & \multirow{2}{*}{$\mathrm{Km}^{2}$} & \multicolumn{3}{|c|}{ Population (Inhabitants) } & \multicolumn{3}{|c|}{ Variation Index: H 1992 = 100} \\
\hline & & 1992 & 2002 & 2011 & 1992 & 2002 & 2011 \\
\hline Băneasa & 110.96 & 6113 & 5554 & 5155 & 100 & 90.9 & 84.3 \\
\hline Călugăreni & 119.37 & 6990 & 6515 & 6149 & 100 & 93.2 & 88.0 \\
\hline Comana & 103.35 & 7954 & 7664 & 7338 & 100 & 96.4 & 92.3 \\
\hline Mihai Bravu & 66.54 & 2786 & 2568 & 2473 & 100 & 92.2 & 88.8 \\
\hline Prundu & 176.51 & 5141 & 4789 & 4328 & 100 & 93.2 & 84.2 \\
\hline Singureni & 57.42 & 3754 & 3236 & 3032 & 100 & 86.2 & 80.8 \\
\hline TOTAL & 634.15 & 34730 & 30326 & 28475 & 100 & 87.2 & 81.9 \\
\hline Population dens & ab. $\left./ \mathrm{km}^{2}\right)$ & 54.8 & 47.8 & 44.9 & & & \\
\hline
\end{tabular}

After 2002, however, communes such as Comana, Mihai Bravu, Prundu, and Singureni began to show a positive net migration rate. Therefore, some parts of this area have become attractive for Bucharest inhabitants. A problem is that usually they want a permanent house and although the study area offers an attractive landscape, the time and costs of daily commuting are far too high, which limits growth in new residents. Another restrictive element is that, for each new construction within the park, new supplementary taxes must be paid.

Nonetheless, the last few years have seen a trend of luring an increasing number of tourists. In 2008, the number of tourists was of approximately 20,000 individuals (Florent \& Toroimac 2012), compared to $30,000-40,000$ in 2013. The majority of visitors to Comana Natural Park are one day and weekend tourists. Lately, an adventure park was designed, offering various recreational activities with organised tracks.

Evolution of number of houses. Nonetheless, the nature of the processes of naturbanization are similar in both cases as the population increases in the area inside or adjacent to the PNAs. The difference is in the pace of change and the beginning of the growth periods. The expansion of the second-home market also has occurred in other European countries, such as France, Switzerland, Italy and Sweden (Sonderegger, 2013), among others. Most of them have become primary residences (Müller, 2012) because of proximity to urban areas and migration to areas with high quality landscape (Bender, 2012).

In the three districts (comarques) that contain portions of the $C-M N P$, the total number of housing units increased by $45.89 \%$ from 1991 to 2011 (Table 5). If we consider only primary residences, the increase is reduced to $39.4 \%$, while second homes increased $54.8 \%$ (Table 6). In Tables 5 and 6 , there is the whole population and surface of these three districts, and because of that, they have more inhabitants and square $\mathrm{km}$ than in Table 3.

\footnotetext{
8 Decree 353/1983, 15 July, Declaration of the Natural Park Cadí-Moixeró.
} 
This situation varies by district, with the greatest growth in Cerdanya (75.91\%) and the least in Berguedà (30.22\%). Cerdanya, being closer to ski areas in both Spain and France and having a broad, flat valley floor, has favoured high- and middle-income tourism.

Berguedà has been undergoing a process of deindustrialization; it has a steeper landscape, and has seen less tourism despite being closer to the BMR.

Tab 5. Number of houses (1991, 2011), main \& second homes (C-M NP Districts). Sources: Household Census 1991 and 2011, Spanish National Institute of Statistics, 2011

\begin{tabular}{|c|c|c|c|c|c|c|c|c|}
\hline \multirow{2}{*}{$\begin{array}{c}\text { Houses } \\
\text { per } \\
\text { District }\end{array}$} & \multicolumn{3}{|c|}{1991} & \multicolumn{3}{|c|}{2011} & \multirow{2}{*}{$\begin{array}{c}\text { Difference, } \\
\text { total h. } \\
2011-1991\end{array}$} & \multirow{2}{*}{$\begin{array}{c}\% \text { of } \\
\text { variation } \\
2011- \\
1991\end{array}$} \\
\hline & $\begin{array}{c}\text { Main } \\
\text { residence }\end{array}$ & $\begin{array}{c}\text { Second } \\
\text { home }\end{array}$ & $\begin{array}{c}\text { Total } \\
\text { houses }\end{array}$ & $\begin{array}{c}\text { Main } \\
\text { residence }\end{array}$ & $\begin{array}{l}\text { Second } \\
\text { home }\end{array}$ & $\begin{array}{c}\text { Total } \\
\text { houses }\end{array}$ & & \\
\hline Alt Urgell & 6,190 & 3,014 & 9,204 & 8,794 & 5,344 & 14,138 & 4,934 & 53.61 \\
\hline Berguedà & 12,7 & 6,742 &, 489 & 16,878 & 8,501 & 25 & 5,890 & 30.22 \\
\hline Cerdanya & 4,050 & 7,994 & 12,044 & 7,665 & 13,521 & 21,186 & 9,142 & 75.91 \\
\hline TOTAL & 22.987 & 17,750 & 40,737 & 33,337 & 27,366 & 60,703 & 19,966 & 49.01 \\
\hline
\end{tabular}

The greatest increase in second homes has occurred in Cerdanya (69.1\%) and Alt Urgell (77.3\%). Nevertheless, we must consider that Cerdanya in 1991 was already a mature touristic area when Alt Urgell was only at the beginning of the tourism extension.

Tab 6. Total population 2011, surface and density of C-M NP Districts. Variation index of housing 1991-2011. Sources: Catalan Institute of Statistics (Idescat), 2011

\begin{tabular}{|c|c|c|c|c|c|c|c|}
\hline \multirow{2}{*}{$\begin{array}{c}\text { Variation index } \\
1991=100.0\end{array}$} & \multicolumn{2}{|c|}{ Main residences } & \multicolumn{2}{|c|}{ Second homes } & \multirow{2}{*}{$\begin{array}{c}\text { Inhabitants } \\
2011\end{array}$} & \multirow{2}{*}{$\begin{array}{c}\text { Surface } \\
\left(\mathrm{km}^{2}\right)\end{array}$} & \multirow{2}{*}{$\begin{array}{c}\operatorname{lnh} / \mathrm{km}^{2} \\
(2011)\end{array}$} \\
\hline & 2001 & 2011 & 2001 & 2011 & & & \\
\hline Alt Urgell & 113.4 & 142.1 & 12 & 177.3 & 22,008 & $1,447.5$ & 15.20 \\
\hline Berguedà & 111.2 & 132.4 & 10 & 126.1 & 4 & $1,184.9$ & 35.06 \\
\hline Cerdanya & 136.9 & 18 & 127.6 & 169.1 & 18,783 & 546.9 & 34.34 \\
\hline TOTAL & 116.3 & 145.0 & 117.1 & 154.2 & 82,331 & $3,179.3$ & 25.90 \\
\hline
\end{tabular}

In figure 8 we present an example of the new artificial landscape as a consequence of the second homes construction in the Cerdanya council, the most touristed district.

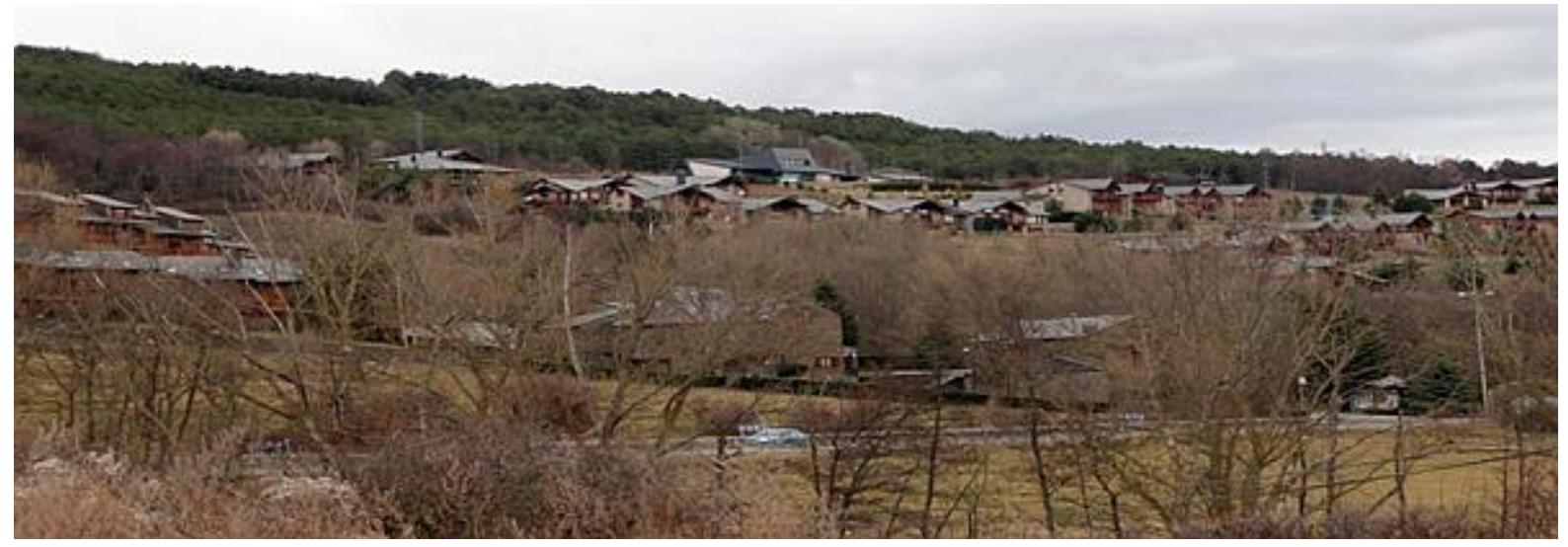

Fig 8. Saga in Ger-Bolvir municipalities, la Cerdanya. Source: Antoni F. Tulla (2013)

In the communes located inside and surrounding the $C N P$, which are smaller in both surface area and population than the districts of $C-M N P$ even though they are closer to Bucharest, the growth in residential construction was only $10.2 \%$ between 1992 and 2011 (Table 7). There were more than 1,100 new dwellings, $82 \%$ of them built after 2000 . No data were available to differentiate between principal residences and second homes. 
Tab 7. Population 2011 and surface of Comana NP Communes. Houses (1992-2011). Sources: Romanian National Institute of Statistics.

\begin{tabular}{|c|c|c|c|c|c|c|c|}
\hline \multirow{2}{*}{$\begin{array}{c}\text { Houses per } \\
\text { Commune }\end{array}$} & \multicolumn{3}{|c|}{$\begin{array}{c}\text { Total houses (main and } \\
\text { second homes) }\end{array}$} & \multirow{2}{*}{$\begin{array}{c}\text { Tot ho. } \\
\text { variation } \\
2011- \\
1992\end{array}$} & \multirow{2}{*}{$\begin{array}{c}\% \text { of } \\
\text { variation } \\
2011- \\
1992\end{array}$} & \multicolumn{2}{|c|}{$\begin{array}{c}\text { Variation index } \\
199=100.0 \\
\end{array}$} \\
\hline & 1992 & 2002 & 2011 & & & 2002 & 2011 \\
\hline Băneasa & 2,229 & 2,224 & 2,408 & 179 & 8.0 & 99.8 & 108.0 \\
\hline Călugăreni & 2,629 & 2,725 & 2,989 & 360 & 13.7 & 103.7 & 113.7 \\
\hline Comana & 2,793 & 2,893 & 3,083 & 290 & 10.4 & 103.6 & 110.4 \\
\hline Mihai Bravu & 993 & 1,025 & 1,086 & 93 & 9.4 & 103.2 & 109.4 \\
\hline Prundu & 1,583 & 1,573 & 1,684 & 101 & 6.4 & 99.4 & 106.4 \\
\hline Singureni & 1,399 & 1,445 & 1,560 & 161 & 11.5 & 103.3 & 111.5 \\
\hline TOTAL & 11,626 & 11,885 & 12,810 & 1,184 & 10.2 & 102.2 & 110.2 \\
\hline
\end{tabular}

Growth was more homogeneous between the communes surrounding CNP than between the districts containing $C-M N P$. Nonetheless, the growth of Călugăreni (13.7\%), Singureni $(11.5 \%)$ and Comana (10.4\%) stand out because they are more related to the natural park. The housing units in these communes are owned by the middle or upper middle class permanent or seasonal population. Meanwhile, in 2013, there were 89 notifications of construction/demolition in the natural park territory, many of them for second residences (CNP Administration).

The difference between these two settings is due to the economic and social level of the inhabitants, the communication infrastructure, the custom of having second residences, and the more acute "back to the land" trend in western Europe.

\subsection{Perception of the naturbanization process and impact at local level}

Based on centralization of results of interviews, we identified the motivations for selection of this area by those who moved, but also the current characteristics and transformations produced in the last years in the two natural parks as effect of the inflow of newcomers and tourists.

\subsubsection{Personal description of the interviewed (Questions 1-9)}

From the perspective of socio-territorial role in C-M NP, $40 \%$ of respondents hold administrative positions at protected area level or in local administration (Table 8). In CNP, the two categories totalize $33 \%$ of respondents. This distribution reflects the sizes of parks, with more employees at the level of management of protected area and local administrations in Catalonia than in Romania. Another category of persons is that of other permanent residents which are more frequent in $C N P$ (37\%) than in the C-M NP (27\%). In Romania, the current trend is to have the permanent residence near big cities (affordable, usually, for those with higher incomes) and less toward second-home construction.

The analysis of respondents depending on the situation with respect to mobility or migration highlights that urban migrants, both national and foreign (either directly or via urban areas, from other countries), dominated in $C-M N P(53 \%)$, but represent a lower percentage in $C N P(33 \%)$. At the same time, half of those interviewed in CNP are native-born individuals who have almost always lived in the area or at some point emigrated for study / work, but returned. In $C-M N P$, in these categories these are $30 \%$ of the interviewed persons.

Tab 8. Socio-territorial position and situation with respect to migration (\%). Source: Own elaboration from interviews

\begin{tabular}{|l|r|l|l|r|r|}
\hline $\begin{array}{l}\text { Socio-territorial } \\
\text { position }\end{array}$ & $\begin{array}{l}\text { Cadí-Moixeró } \\
\text { Park (C-M NP) }\end{array}$ & $\begin{array}{l}\text { Comana } \\
\text { Park } \\
\text { (CNP) }\end{array}$ & $\begin{array}{l}\text { Situation related } \\
\text { to migration }\end{array}$ & $\begin{array}{l}\text { Cadí-Moixeró } \\
\text { Park (C-M NP) }\end{array}$ & $\begin{array}{l}\text { Comana } \\
\text { Park } \\
\text { (CNP) }\end{array}$ \\
\hline A-PkMang & 17 & 13 & Local & 10 & 27 \\
\hline B-LocAdm & 23 & 20 & LocReturn & 20 & 23 \\
\hline C-TecResch & 17 & 17 & UrbMigrat & 47 & 33 \\
\hline D-PermResid & 27 & 37 & SecHomes & 17 & 17 \\
\hline E-TempResid & 16 & 13 & ForeignUM & 6 & 0 \\
\hline
\end{tabular}


The structure by gender of the respondents shows that 12 women and 18 men were interviewed in C-M NP and 13 women and 17 men in CNP. In both protected areas, $43 \%$ of respondents are aged between 20-40 years old, and well-represented is the category between 40-60 years old (Figure 9). In general, the selected individuals held a broad view of the territory.

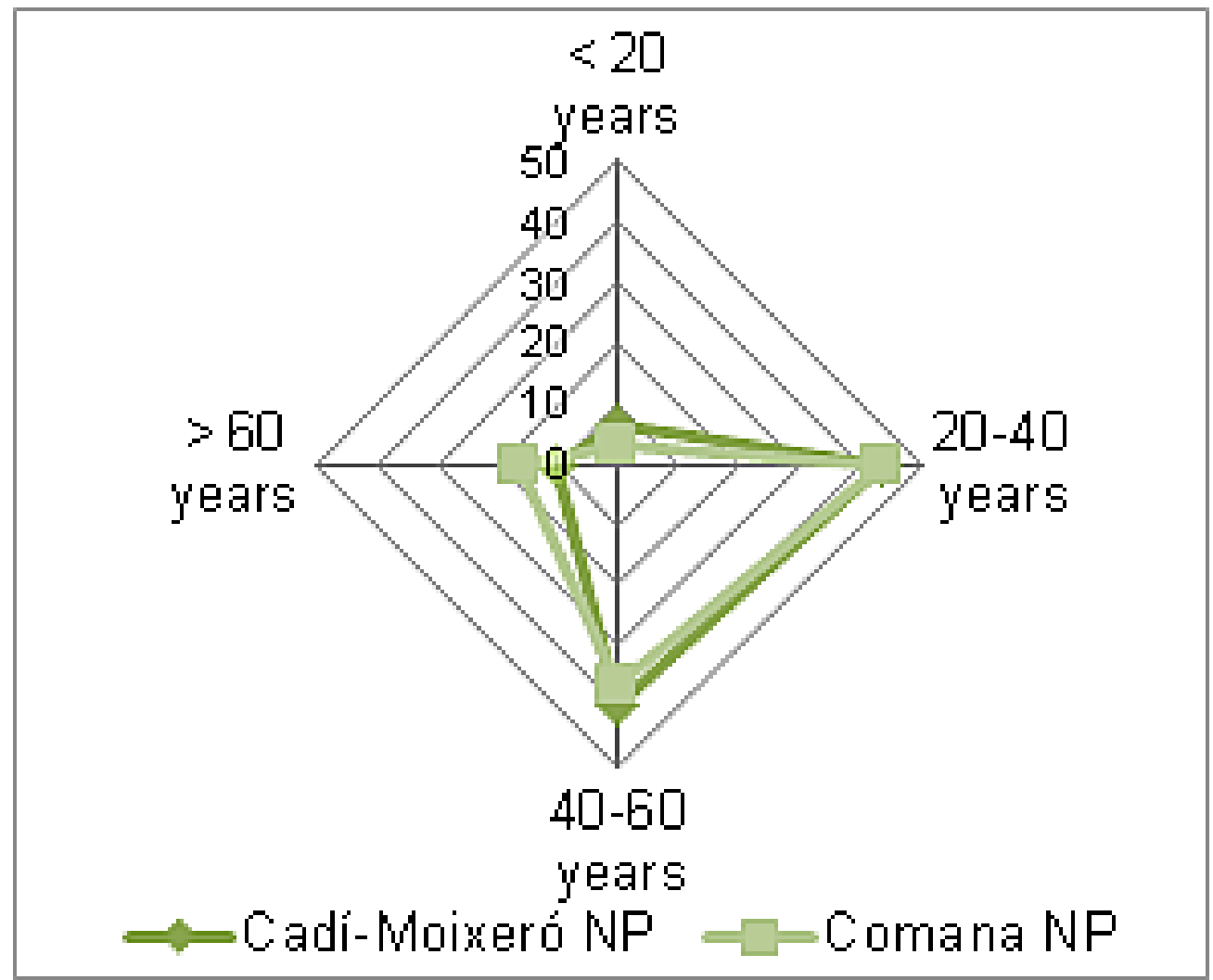

Fig 9. Age distribution (\%). Source: Own elaboration from interviews

The analysis of professional status highlights that the majority (over $80 \%$ ) of those interviewed in both areas fell into the category of occupied population. Among them, a considerable portion (40\%) of those from $C-M N P$ are self-employed, being involved in a family business/farm, while more than a quarter work in various positions in the local administration.

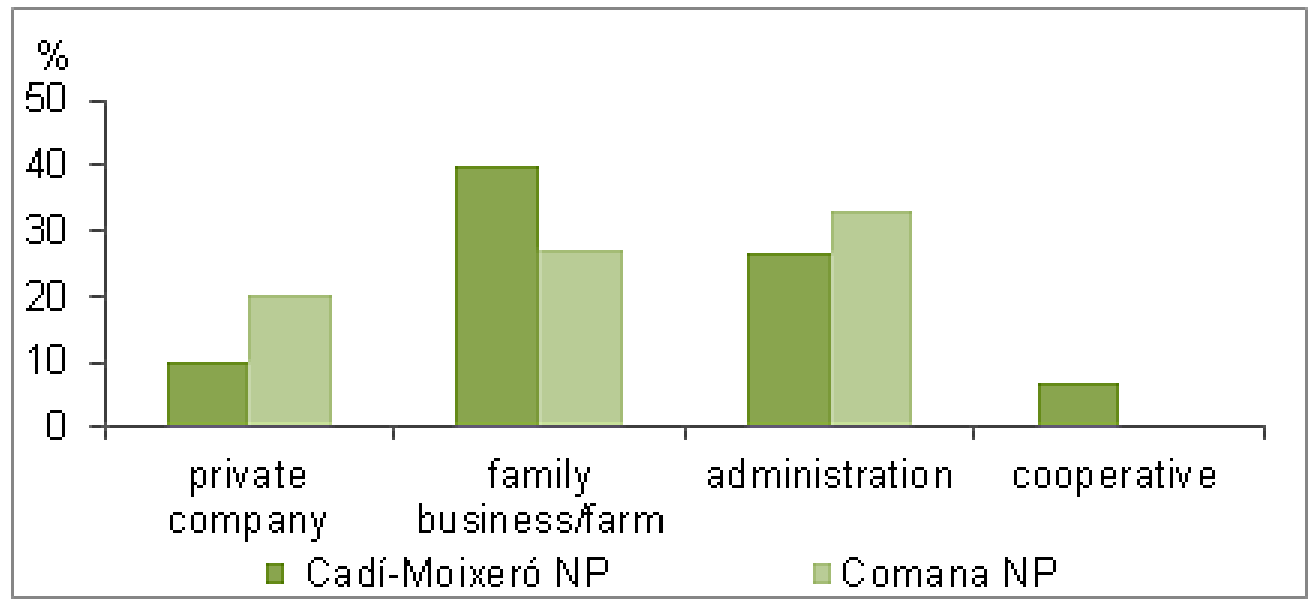

Fig 10. Type of work organization / institution. Source: Own elaboration from interviews

In $C N P$, a large portion (33\%) is involved in the local administration of the communes and natural park (Figure 10). More than a quarter of the occupied population work in their own households or 
as entrepreneurs, usually being involved in traditional activities (especially agriculture) or developing small businesses.

\subsubsection{The migration process (Questions 10-13)}

The magnitude of the migration process was evaluated and the majority $(73 \%$ in $C-M N P$ and $77 \%$ in $C N P$ ) consider that in recent years many people have moved into the area. Analysis of the data showed that in CNP half of the respondents were born there and $20 \%$ had moved to the area more than 10 years earlier, similar to the $C-M N P$ data $(70 \%)$ for these two categories (Figure 11).

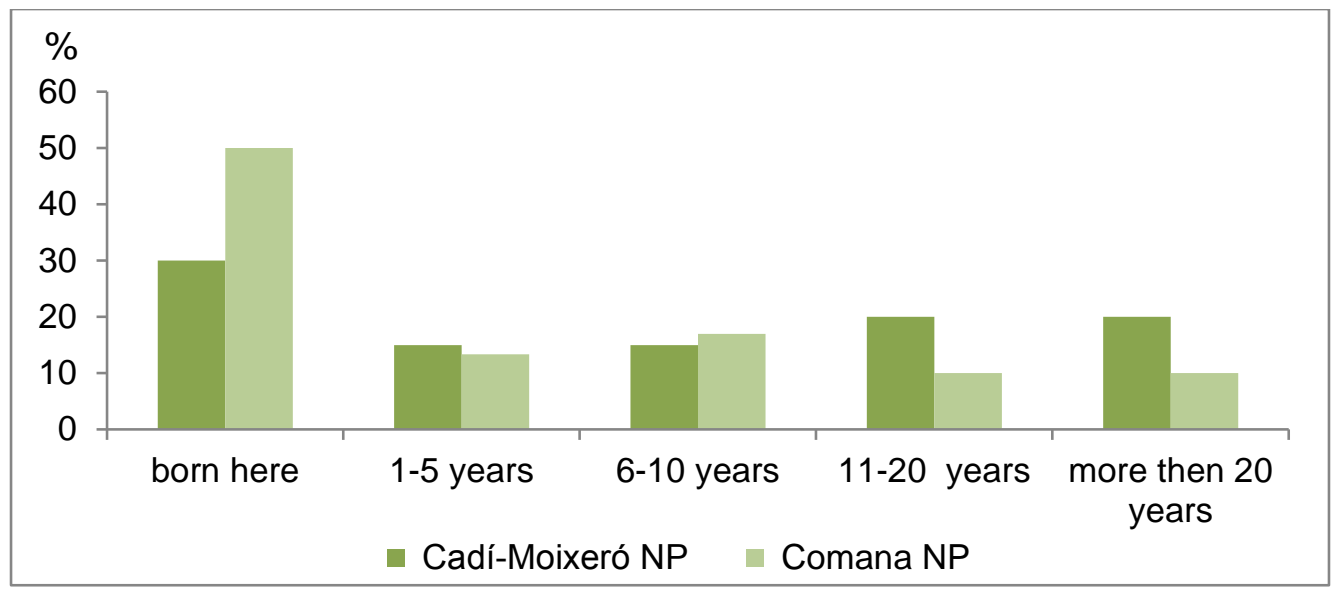

Fig 11. Personal history of living in this area. Source: Own elaboration from interviews

The reasons for choosing $C-M N P$ as a residence or returning to the native area highlight that the most important factor, at moving time, was the landscape (33\%), while in CNP the greatest attraction (36\%) it was the lower price of land or houses (Figure 12). However, in both countries, migration also occurs for employment opportunity. In this regard, $C-M N P(26 \%)$ was more attractive than $C N P(10 \%)$, or job opportunities were combined with the quality of the landscape.

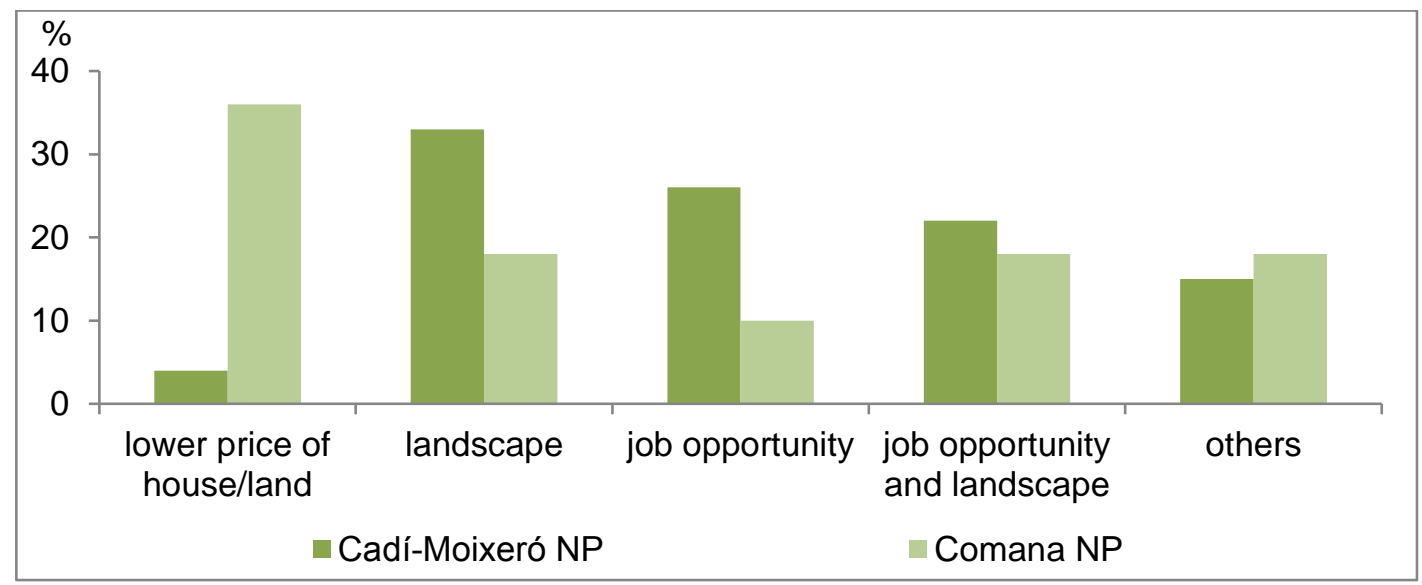

Fig 12. Reasons for moving to this area. Source: Own elaboration from interviews

Accessibility is considered one of the factors which influence an area's attractiveness. Therefore, we investigated the perception of accessibility by public transportation, which most of the respondents in $C-M N P(63 \%)$ considered deficient (Figure 13). One of the explanations could be that it is a mountainous area, farther from Barcelona, with limited connections. In contrast, over half of $C N P$ respondents considered accessibility to be good, as the link to Bucharest is provided by minibuses. However, an obstacle would be that the ensured frequency is not satisfactory. Accessibility by private transportation was assessed in $C-M N P$ as either poor or good, in relation to slow roads in CNP. Nevertheless, private transportation was perceived as 
accessible in CNP by all respondents who could afford a car. Therefore, accessibility is not considered a problem in $C-M N P$, compared with $C N P$.

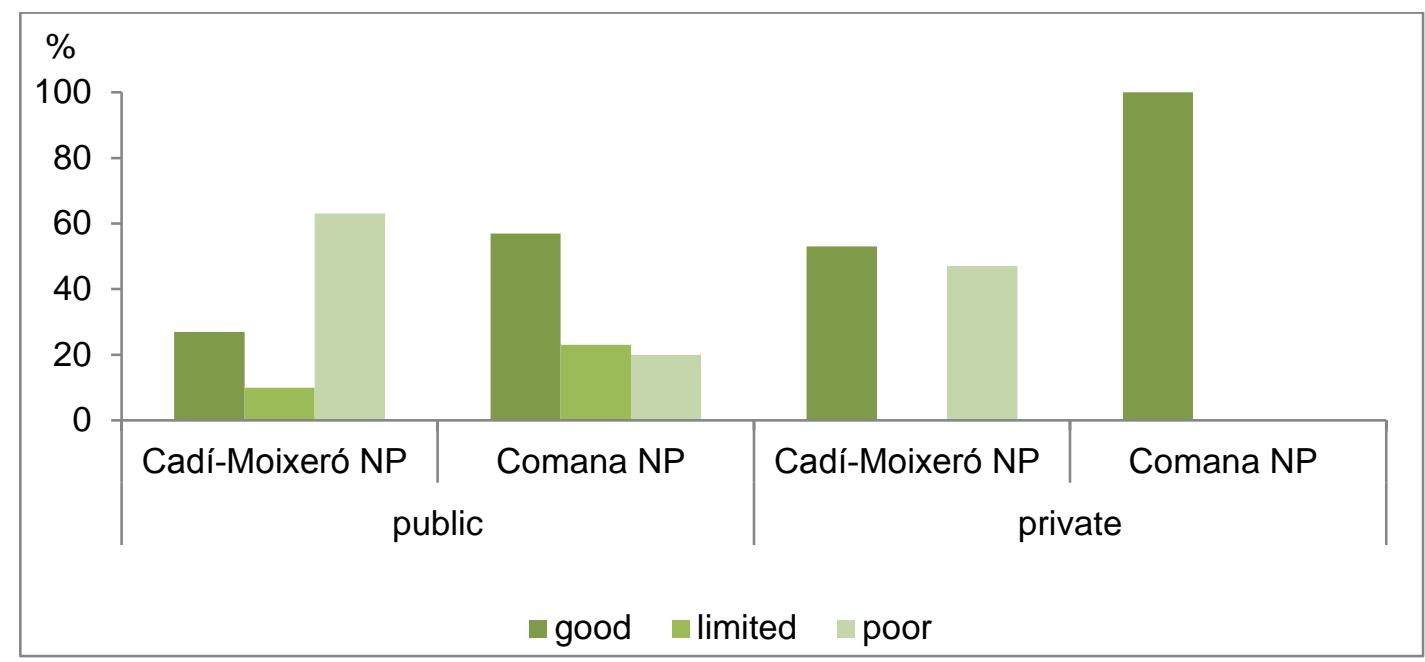

Fig 13. Accessibility by transportation. Source: Own elaboration from interviews

\subsubsection{Local characteristics/resources and the new economic activities which can contribute to rural development (Questions 14-20)}

The general characteristics of the analysed areas were investigated in the light of perception of positive and negative elements. Among the perceived benefits, the most appreciated was the quality of the landscape, with forests and clean air, for nearly $70 \%$ of the respondents. Pluriactivity is considered as a benefit in $C-M N P$ by half of the respondents, many of them trying to develop their own business, compared with $20 \%$ in CNP (Figure 14). The communities of the $C$ $N P$ already had a strong tradition in tourism and crafts, compared with the $C N P$, where activities other than agriculture were developed more recently.

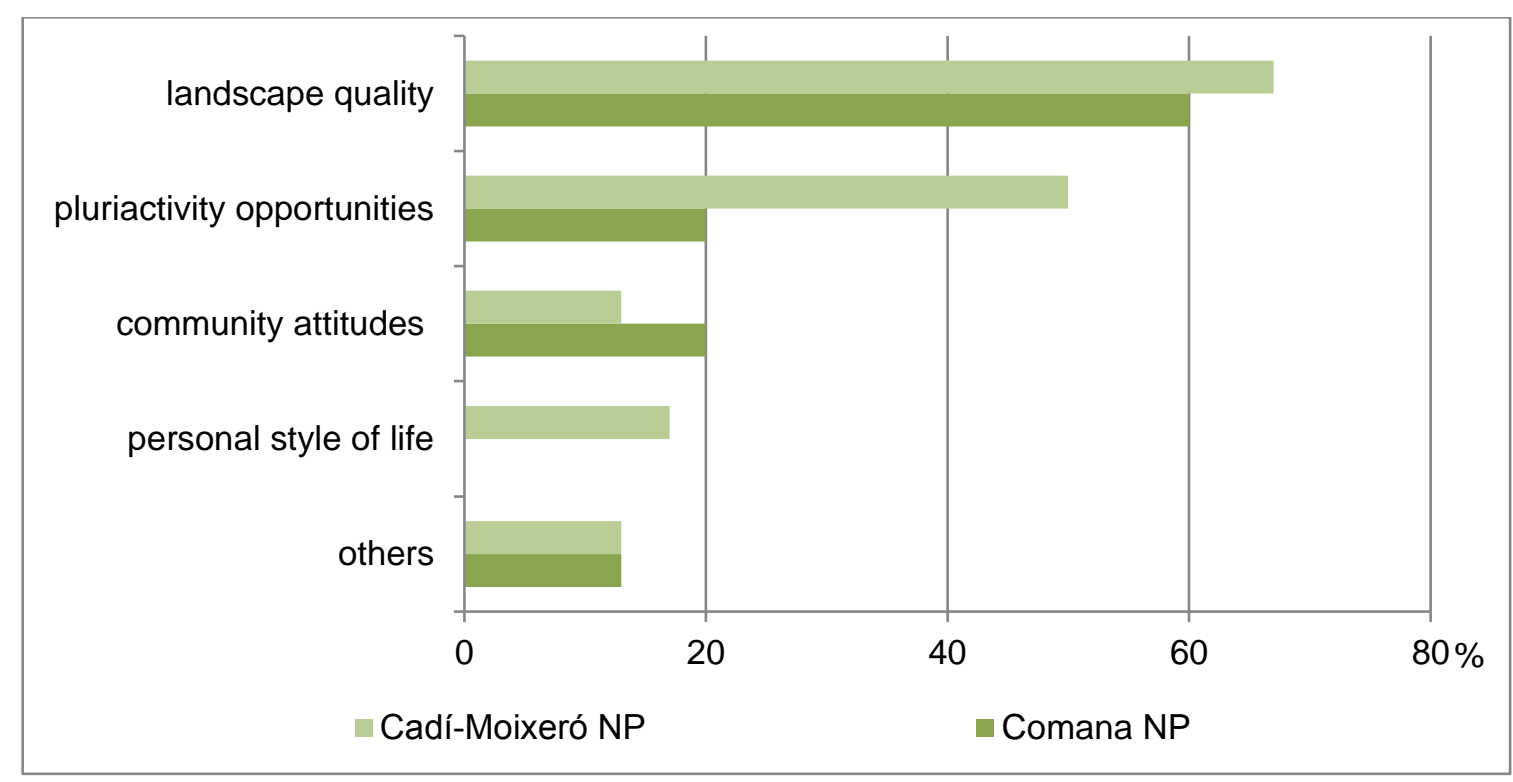

Fig 14. Positive elements for the area (more than one answer). Source: Own elaboration from interviews

The opinions related to the negative elements in the two areas are clearly very different. The large number of tourists is considered to have a more restrictive impact in $C-M N P(43 \%)$ than in $C N P$ (17\%), where the lack of infrastructure affects more people (47\%), compared to C-M NP (20\%) (Figure 15). The highly developed tourism industry also brings about reactive attitudes, 
demonstrating that traditional activities in CNP have not yet been replaced by new types of jobs related to tourism, as occurred in $C-M N P$. Therefore, the respondents are dissatisfied with the decline of certain traditional activities, generally related to agriculture. The rules imposed by the administration and park authorities are considered a disadvantage for both areas (33\% and $13 \%$, respectively). Given that CNP was declared a natural park more recently, the rules imposed by living in a protected area are perceived as highly restrictive. In $C-M N P$, some respondents considered second homes an unfavourable element which induces local landscape changes.

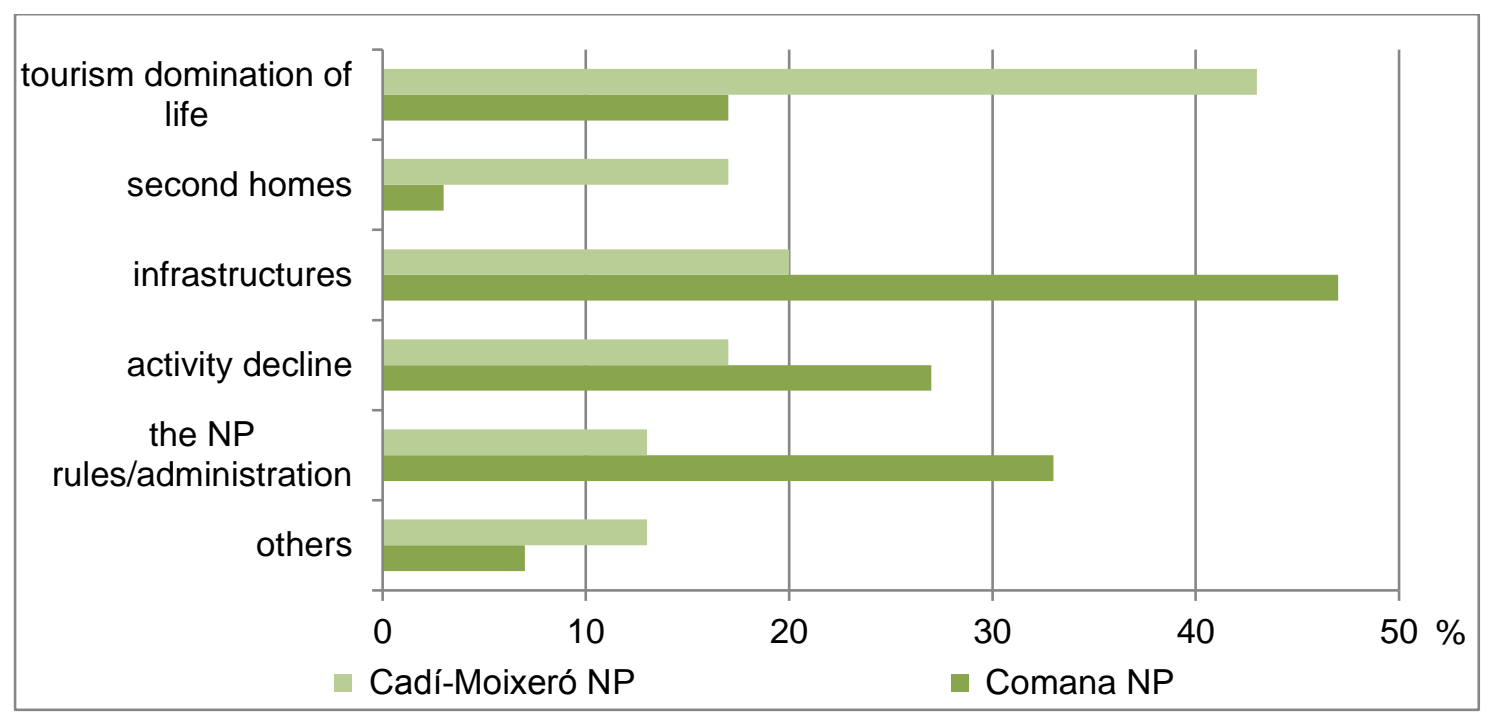

Fig 15. Negative elements for the area (more of one answer). Source: Own elaboration from interviews

In terms of new activities which can produce added value to promote local development, tourism was perceived to be a very important activity in both PNAs (Figure 16).

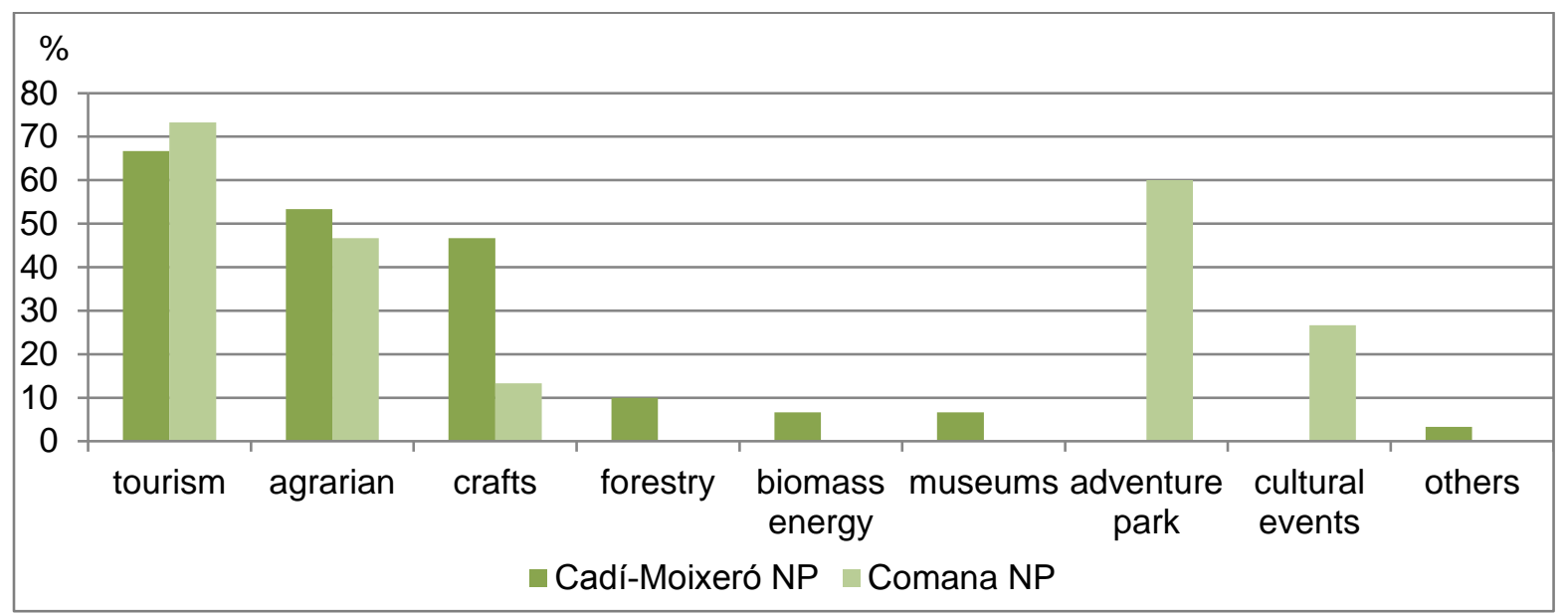

Fig 16. New activities which can produce added value to promote local development. Source: Own elaboration from interviews

In C-M NP, there are various forms of tourism, while in CNP one-day and weekend tourism prevail. This is influenced by the proximity to the capital city, a lack of visitor accommodations, and recent development of tourist activities such as the adventure park, which is considered to be very important for the development of local economy. By correlating this question with the previous one, we can see that tourism is perceived as a negative element, while at the same time, the respondents identify it as a strong generator of income.

In both areas, the respondents appreciate the agricultural strengths of the areas, also taking into account local traditions. In $C-M N P$, other activities important in promoting local development are 
crafts, as well as with other local resources. This demonstrates considerable endogenous potential that can support the local communities.

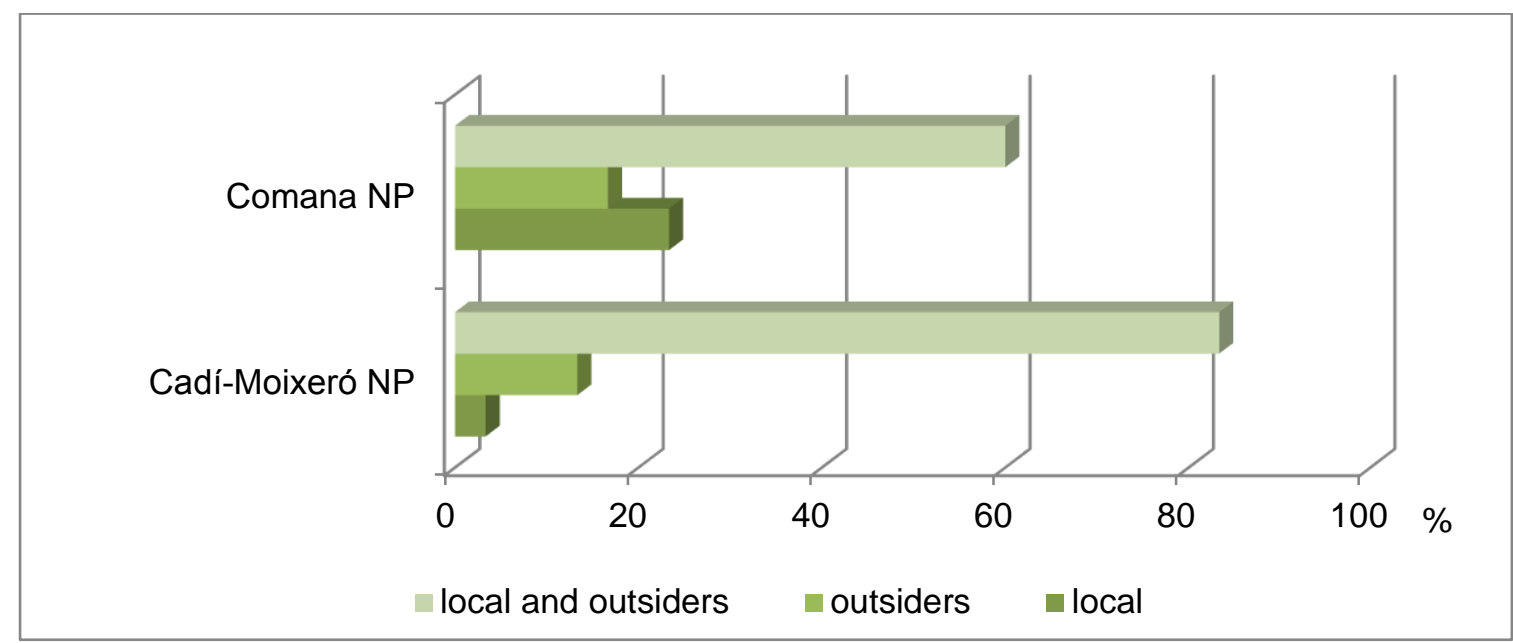

Fig 17. The origins of promoters of new activities. Source: Own elaboration from interviews

The origins of people who have developed activities in recent years show that the majority had roots both within and outside the study areas (Figure 17). In CNP, some entrepreneurs had worked abroad or in urban areas, returning during recent years. Thus, we can see that those who moved into these areas are involved in development of economic activities based on local resources. This is also influenced by the specific retail and services needs of seasonal visitors, while permanent residents are focused on having jobs and basic services.

All the respondents believed that these new activities can stimulate the economic growth of the area for several reasons, such as attracting tourists, the possibility of creating a market for local products, etc.

\subsubsection{Local community and rural culture (Questions 21-25)}

The local conditions can record transformations on the background of actions of newcomers and the constant pressure of tourists. The relationships between the people living in the area for a long time (> 10 years) and the newcomers are relatively good (sometimes good, sometimes tense) or even good for a majority of respondents in both areas (Figure 18).

The influence on the local culture of newly arrived persons (including the entrepreneurs) in $C-M$ $N P$ is considered significant. Thus, the newcomers are trying to adapt, but they also come up with new ideas that sometimes lead to the emergence of conflicts with local people.

Overall, in terms of interaction between the newcomers and the long-term inhabitants in CNP, two types of attitudes can be identified. Part of the population have a passive, indifferent attitude toward naturbanization changes, characteristic of those who continue to practice traditional activities and do not engage with newcomers.

At the same time, there is an active attitude, generally represented by entrepreneurs who are involved in tourism and would like more public investments (particularly in infrastructure) and by the ones who build new homes or develop new activities, etc. 


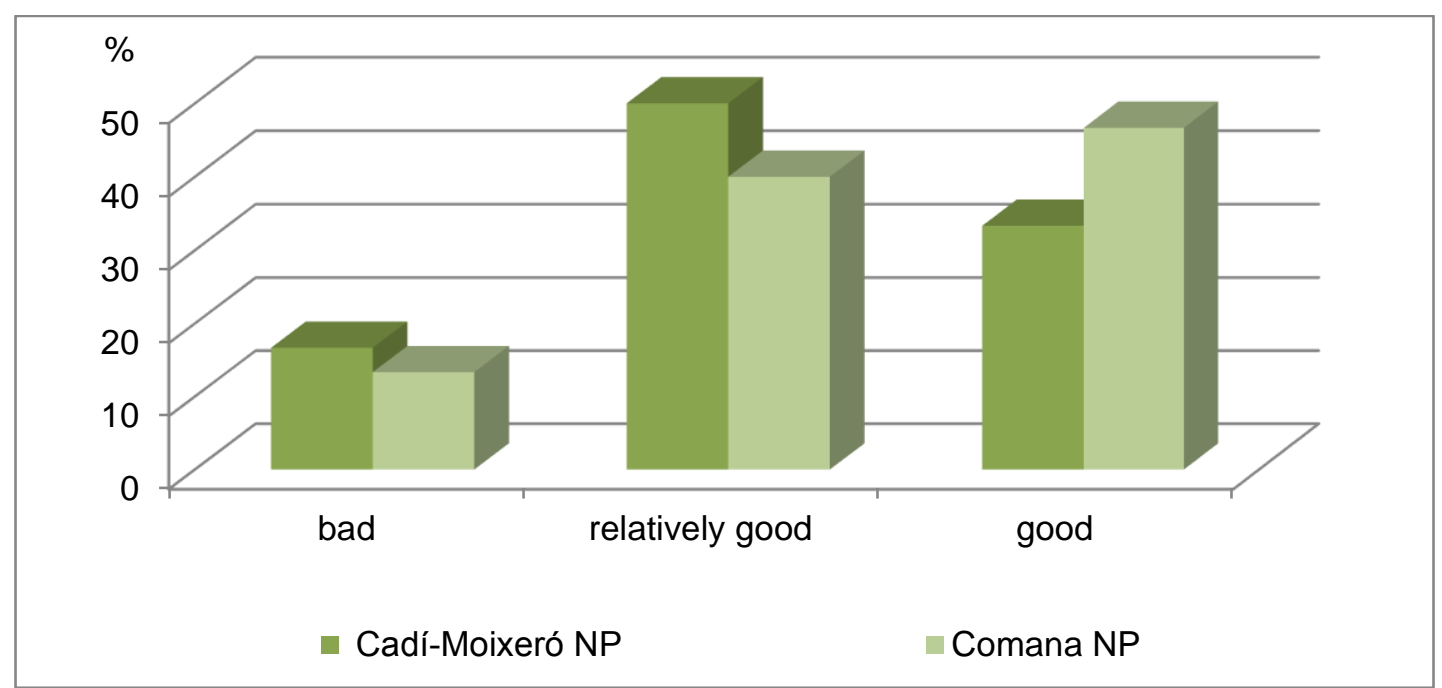

Fig 18. Relations between the people living in the area for a long time and the newcomers. Source: Own elaboration from interviews

Disagreements about land use and the development of tourism activities create problems for relationships between the local population and newcomers, and with park managers and local administration, in both countries. The way of life in the areas surrounding both NPAs is considered by the majority of respondents to be closer to rural than urban conditions, showing that the new activities developed did not succeed in inducing major changes at local level. However, certain urban characteristics may be found in CNP, given the proximity to Bucharest (Figure 19).

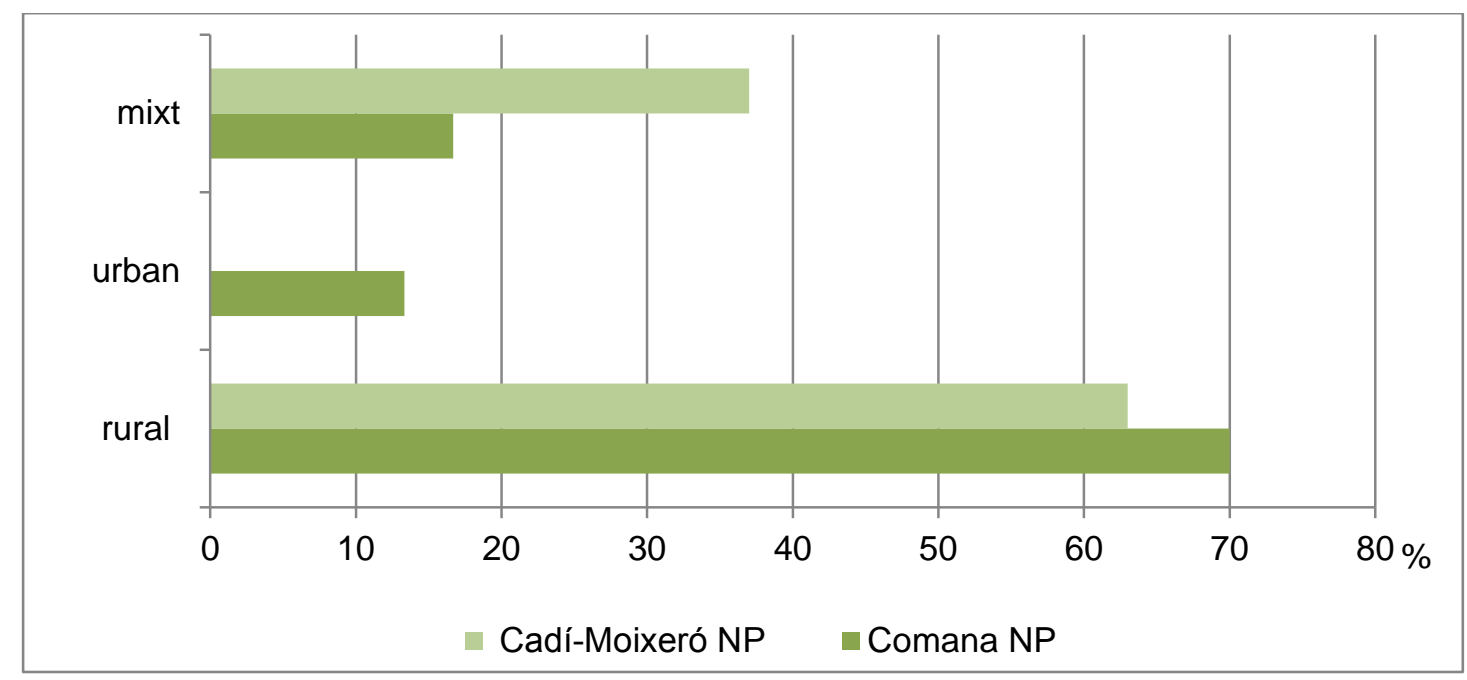

Fig 19. Urban / rural way of life. Source: Own elaboration from interviews

It was possible to distinguish the relationship between locals and permanent residents who try to integrate with rural local life from that group's interactions with seasonal residents, who usually attempt to maintain an urban lifestyle. In any case, people tended to participate in traditional festivals in both countries. In both areas, the local culture has been modified under the influence of newcomers, especially if new entrepreneurs have settled in the community.

In the $C-M N P$, the rural culture has been modified, mainly in Cerdanya, and in some way it has been maintained, as in Alt Urgell. A major conflict was reported between the local population and seasonal residents. In Cerdanya, many new second homes have been built, destroying the landscape but enriching the native population that was able to sell land at a good price. This does not keep the permanent and seasonal residents from having problems getting along and having to come to agreement about cultural and economic activities in the area. For example, the churches no longer ring their bells between 10 o'clock at night and 8 o'clock in the morning 
on weekends. Many village festivals have been moved to the summer and are filled with activities demanded by the population coming from an urban culture. In CNP, given that the number of tourists and temporary population is more reduced, their impact for now does not have the same breadth compared to the situation from $C-M N P$.

\section{Conclusions}

The paper has analysed the naturbanization processes generated in two different rural natural areas; Cadí-Moixeró NP (Catalonia, Spain) and Comana NP (Bucharest, Romania). Naturbanization studies are focused on the demographic and socio-economic impacts produced as a consequence of the progressive increase of population migration in and around a NPA.

The choice of two metropolitan areas as diverse as Barcelona and Bucharest allowed the comparison between the naturbanization processes derived from the impact of an urban metropolitan region with an international presence and the naturbanization processes influenced by one with a more national profile, although the city aspires to be a reference for Eastern Europe (Espon GROSEE Project, 2013).

The research also allowed identification of signs of naturbanization processes in both areas in terms of increased newcomers and housing construction related with the landscape quality of the PNAs. The process is heightened in C-M NP, compared to CNP, where it maintains a constant level of departures of population concomitantly with arrivals. However, we can see that the local impact can be significant without having an increase of total population. For example, a native returned to the CNP and built an adventure park,which led to the significant increase in the number of tourists.

Between 1991 and 2011, the number of houses increased $45.9 \%$ in C-M NP, while in CNP the growth was only $10.2 \%$. Significant differences in the rhythms, intensities and typologies of the two PNAs clearly derived from the different geographical and socio-economic contexts. Firstly, the greater population of the BMR, together with the higher purchasing power, compared to BMA, are deciding factors that exert more pressure on the C-M NP area. Secondly, the greater distance from C-M NP to BMR than from CNP to BMA, explains the importance of second homes in the CNP area and the greater importance of day visitors in CNP. Likewise, in Spain the second-home phenomenon was the largest in Europe.

The results of interviews highlight that in C-M NP the newcomers were attracted by the landscape values, but also by job opportunities, which highlight the entrepreneurial dynamics of this area. In CNP, the lower price of the land/home was one of the main reasons for moving to the area, even if the landscape represented one of the important elements. Thus, regardless of the reasons which led to the selection of this area, over $60 \%$ of those interviewed in both PNAs identify among the current positive elements the beauty of the landscape and the peacefulness of the site. Pluriactivity is considered as another advantage in C-M NP by half of the respondents, while in CNP it has a lesser role.

In relation to the social and economic impacts, the negative elements clearly differ. Tourism is considered a restrictive element in C-M NP, while in CNP infrastructure is appreciated as underdeveloped. This indicates the two elements which block local sustainable development in the area. The opinions regarding the new activities which can produce added value to promote local development indicate tourism as the main economic resource in both areas. Although it represents an element which deteriorates in C-M NP, yet the economic reasons prevail. The commodification of the rural natural space is more highly developed in C-M NP, resulting in more job opportunities associated with eco-tourism and craft food and art products, whereas adventure and cultural events are more remarkable in CNP.

C-M NP area is a mountainous zone where traditional cattle and dairy production is only possible with EU funding support and through transforming primary goods to value-added products associated with rural development and local food networks. These efforts need to be addressed to specific market targets closely linked with ecotourism and mountain tourism. The CNP area is highly specialised in intensive agricultural production and is close to an urban concentration. Only recently, other local resources have begun to be exploited. Both areas combine agricultural 
production with tourism but the C-M NP profile shows a higher necessity for alliance with urban demand, whereas CNP land use specialization competes well with urban pressure to gain a better position.

The local community and rural culture record transformations under the influence of newcomers and the constant pressure of tourists. However, confrontation between locals and newcomers, mainly the seasonal residents, tends to be higher in C-M NP, as well as land use disputes. This is a result of the more intensive urban pressure but also a consequence of stricter regulation. Some conflicts also exist between park management and the local population in CNP, and between natural park managers and local public administrations, over land use, activities, permits, park admission, the priorities for new housing to increase tourism, etc.

Those involved in the management of protected areas and in public administration have an important role which can condition the actions carried out forthe environmental preservation measures. The difficulty of integrating local authorities' approach to how the area should evolve with the natural park management's approach is remarkable. Management of the natural park has more historical legal protection in Catalonia than in Romania. C-M NP was created in 1983 and CNP was established much later (2004), although two small areas of flora were recognized as scientific reserves in 1954 (Management Plan of the Comana NP, 2013). The C-M NP tradition of more than 30 years of environmental protection was reflected in the interview results, as responses showed that (a) more information about the natural park was available from tourist offices and cultural promotions to the general public in Spain than in Romania and (b) there was better coordination between public administrations and natural park management through the parks boards in Spain than in Romania. The latter may be due to the creation and management of natural parks as the responsibility of the autonomous communities' governments in Spain (Catalan government in the case of Cadí-Moixeró), while in Romania the central government is responsible. Thus, regarding the new governance paradigm ${ }^{9}$, decentralization of PNAs management may permit a better integration and coordination with other related policies.

In terms of the potential to develop environmentally friendly built-up areas, the research showed that the starting point is common in both areas: the will to spend time, seasonally and also permanently, close to a NPA. This is influenced by the transport and communications conditions, by purchasing power, by the distance between the urban and rural-natural areas and by the job opportunities at both sites: the urban centre as expulsor and the rural-natural centre as host. In both cases, the trend brings about new opportunities for these natural-rural areas, both being tourist destinations and receiving urban pressure in different modalities (second homes vs day visitors). Both areas hold significant environmental and heritage values that constitute the main assets of their economies. In the face of the urban-rural dynamics, the challenge is to deal with dissimilar interests calling natural parks policies into question.

The analyses allowed the identification of naturbanization processes facing heavy pressure but at the same time offering strategic frames to lead sustainable practices, both conditioned by the availability of material and immaterial resources. Taking up Halfacree's triad (Halfacree, 2007) to balance physical space needs with the mental construct of space and the symbolic space as a framework to develop sustainable rural areas, helped to identify a better equilibrium in C-M NP, although the area needs to control second homes and display measures to encourage permanent residents through social housing, in order to guarantee environmentally friendly built-up areas.

In C-M NP, people understand that the existence of the park has potential for strategic actions in local development. In CNP, the local population, in confronting some entrepreneurs, still does not realize the importance of the natural area, or the benefits that might be achieved through the development of sustainable forms of tourism. The area is not properly advertised, so people living in Bucharest are not aware of it. The number of tourists is expected to increase with better promotion of this area. Yet, in this context, the anthropic pressure on the NPA will intensify, so conservation measures need to be enhanced.

\footnotetext{
${ }^{9}$ Agreement of the Catalan Government (Acord Govern/21/2015, de 17 de febrer) about of "Pla de gestió dels espais naturals de protecció especial de Catalunya, 2015-2020".
} 
Finally, in both cases, the natural park's board has insufficient funds to deal with the new socioeconomic demands. From this perspective, it can be deduced that C-M NP should move towards an environmental label like the European Charter of Sustainable Tourism (CETS) and CNP should explore the Agrarian Park formula in order to preserve and sustain agriculture activity.

\section{Acknowledgments}

We appreciate the funding support by project grants: CSO 2012-31979 (IP: Antoni F. Tulla), CSO 2015-65257-R (IP: Anna Badia) and 2014 SGR-1090 (IP: Montserrat Pallarès-Barberà) in Spain, and UB 1322 (Integrated and sectorial analyses in trans-scalar territorial dynamics, IP: Zamfir Daniela) in Romania.

\section{Academic references}

[1] Andersson, K., Eklund, E. \& Lehtola, M. (2009). Farmers, businessmen or green entrepreneurs? Producers of new rural goods and services in rural areas under urban pressure. Journal of Environmental Policy \& Planning 11(1), 29-43. DOI: $10.1080 / 15239080902774960$.

[2] Badia, A., Tulla, A. F. \& Vera, A. (2010). Los incendios en zonas de interfase urbano forestal. La integración de nuevos elementos em el diseño de la prevención. Scripta Nova. Revista electrónica de geografía y ciencias sociales 14(331).

[3] Baumgartner, D., Pütz, M. \& Seidl, I. (2013). What Kind of Entrepreneurship Drives Regional Development in European Non-core Regions? A Literature Review on Empirical Entrepreneurship $\frac{\text { Research. European Planning }}{\text { Studies }} \frac{\text { 21(8), }}{1095-1127 .}$ DOI: $10.1080 / 09654313.2012 .722937$.

[4] Bender, O. \& Kanitscheider, S. (2012). New immigration into the European Alps: emerging research issues. Mountain Research and Development, 32(2), 235-241. DOI: 10.1659/MRDJOURNAL-D-12-00030.1.

[5] Berry, B. J. L. (1976). The counterurbanization process: Urban America since 1970. In Berry, B. J. L., ed., Urbanization and counterurbanization (pp.17-30). Beverly Hills, Ca: Sage.

[6] Best, S. (1989). The commodification of reality and the reality of commodification: Jean Baudrillard and post-modernism. In Wilson, J., ed., Current Perspectives in Social Theory (pp. 23-51). Bingley: Emerald.

[7] Bosworth, G. (2010). Commercial counterurbanisation: an emerging force in rural economic development. Environment and Planning A, 42(4), 966-981. DOI: 10.1068/a42206.

[8] Champion, A. G. (1989). Counterurbanization: the conceptual and methodological challenge. In Champion, A. G., ed., Counterurbanization: The Changing Pace and Nature of Population Deconcentration (pp. 19-33). London: Edward Arnold.

[9] Calvache, M. F., Prados, M. J. \& Lourenço, J. M. (2016). Assessment of National Parks affected by naturbanization processes in Southern Europe. Journal of Environmental Planning and Management 59(9), 1629-1655. DOI: 10.1080/09640568.2015.1083416.

[10] Chape, S., Spalding, M. D. \& Jenkins, M. D. (2008). The World's Protected Areas: Status, Values and Prospects in the $21^{\text {st }}$ Century. Berkeley and Los Angeles: University of California Press.

[11] Cloke, P. (1993). The countryside as commodity: new rural spaces for leisure. In Glyptis, S., ed., Leisure and the Environment. London: Bellhaven.

[12] Crofts, R. (2004). Linking Protected Areas to the Wider World: A Review of Approaches." Journal of Environmental Policy and Planning 6(2): 143-156. DOI: $10.1080 / 1523908042000320722$. 
[13] Domínguez García, M. D., Swagemakers, P., Bock, B. B. \& Simón Fernández, X. (2012). Making a Living: Grassroots development initiatives, natural resource management and institutional support in Galicia, Spain. European Countryside 4(1), 17-30. DOI: 10.2478/v10091-012-0011-x.

[14] Elbersen, B. S. (2001). Nature on the Doorstep. The Relationship between Protected Natural Areas and Residential Activity in the European Countryside. Wageningen: ALTERRA.

[15] Elbersen, B. (2005). Combining Nature Conservation and Residential Development in The Netherlands, England and Spain. Journal of Environmental Planning and Management, 48(1), 37-63. DOI: 10.1080/0964056042000308148.

[16] Elden, S. (2004). Understanding Henri Lefebvre. Theory and the Possible. London, New York: Continuum.

[17] Florent, L. \& Toroimac, G. (2012). Tourist attractiveness of Ramsar wetlands. Case study: Lakes of Champagne Humide (France) and Comana NP (Romania). In Gâştescu, P., Lewis, J. W. \& Breţcan. P., eds., Water resources and wetlands (pp. 530-535). Bucureşti: Editura Transversal.

[18] Gosnell, H. \& Abrams, J. (2011). Amenity migration: diverse conceptualizations of drivers, socioeconomic dimensions, and emerging challenges. GeoJournal 76(4), 303-322. DOI: $10.1007 / \mathrm{s} 10708-009-9295-4$.

[19] Gurrutxaga, M. \& Lozano, P. (2009). La Integración de la Conectividad Ecológica en los Instrumentos de Ordenación y Planificación Territorial: Una Revisión. Boletín de la Asociación de Geógrafos Españoles 49, 45-66.

[20] Halfacree, K. (2007). Trial by space for a 'radical rural': Introducing alternative localities, representations and lives. Journal of Rural Studies 23(2), 125-141. DOI: 10.1016/j.jrurstud.2006.10.002.

[21] Halfacree, K. (2012). Heterolocal Identities? Counter-Urbanisation, Second Homes, and Rural Consumption in the Era of Mobilities. Population, Space and Place 18(2), 209-224. DOI: $10.1002 / p s p .665$.

[22] Haugen, M. S. \& Vik, J., (2008). Farmers as entrepreneurs: the case of farm-based tourism. International Journal of Entrepreneurship and Small Business, 6(3), 321-336. DOI: 10.1504/IJESB.2008.01913.

[23] Horlings, L. G. \& Marsden, T. K. (2014). Exploring the 'New Rural Paradigm' in Europe: Ecoeconomic strategies as a counterforce to the global competitiveness agenda. European Urban and Regional Studies 21(1), 4-20. DOI: 10.1177/0969776412441934.

[24] Ianoș, I., Cercleux, A. L. \& Pintilii, R. (2010). Remarks on identity building of rural and urban communities in the Bucharest Metropolitan Area. Analele Universității din Oradea - Seria Geografie 20(2), 173-183.

[25] lanoș, I. et al. (2014). București și zona sa metropolitană. Privire comparativă cu Sofia și Atena. București: Editura Universitară.

[26] Lefebvre, H. (1991). The Production of Space. Oxford: Blackwell.

[27] Lordkipanidze, M., Brezet, H. \& Backman, M. (2005). The entrepreneurship factor in sustainable tourism development. Journal of Cleaner Production, 13(8), 787-798. DOI: 10.1016/j.jclepro.2004.02.043.

[28] Marsden, T. (2003). The condition of rural sustainability: issues in the governance of rural space in Europe. In Kasimis, Ch. \& Stathakis, G., eds., The Reform of the CAP and Rural Development in Southern Europe (p. 19), Aldershot: Ashgate Publishers.

[29] McConville, A., Underwood, E., Green, S. \& Kettunen, M. (2014). Planning and implementing green infrastructure on a regional level in Romania Ecological restoration of Comana wetlands in Giurgiu County in Financing Natura 2000 in 2014-2020. In Kettunen, 
M. \& Torkler, P, eds., Guidance Handbook, Part II - case studies (pp. 130-132). Luxembourg: Publication Office of the European Union. DOI: 10.2779/19708.ml.

[30] Marull, J., Pino, J., Tello, E. \& Cordobilla, M. J. (2010). Social Metabolism, Landscape Change and Land-Use Planning in the Barcelona Metropolitan Region. Land Use Policy 27(2), 497-510. DOI:10.1016/j.landusepol.2009.07.004.

[31] Mitchell, C. J. A. (2004). Making sense of counterurbanization. Journal of Rural Studies 20(1), 15-34. DOI: 10.1016/S0743-0167(03)00031-7.

[32] Morris, C. \& Kirwan, J. (2011). Ecological embeddedness: aninterrogation and refinement of the concept within the context of alternative food networks in the UK. Journal of Rural Studies, 27(3), 322-330. DOI: 10.1016/j.jrurstud.2011.03.004.

[33] Müller, D. K. \& Marjavaara, R. (2012). From Second Home to Primary Residence: Migration towards recreational properties in Sweden 1991-2005. Tijdschrift voor Economische en Sociale Geografie 103(1), 53-68. DOI: 10.1111/j.1467-9663.2011.00674.x.

[34] Muñoz, F. (2007). La producción residencial de baja densidad en la provincia de Barcelona. In Indovina, F., ed., La ciudad de baja densidad: Lógicas, gestión y contención. Barcelona: Diputación de Barcelona.

[35] Muñoz, F., ed. (2011). Estratègies vers la ciutat de baixa densitat: de la contenció a la gestió. Barcelona: Col. Estudis, Diputació de Barcelona.

[36] Nel·lo Comon, O. (2001). Ciutat de ciutats. Reflexió sobre el procés d'urbanització a Catalonia. Barcelona: Editorial Empuries.

[37] Nel·lo Comon, O. (2011). Estrategias para la contención y gestión de las urbanizaciones de baja densidad en Cataluña. Ciudad y Territorio: Estudios Territoriales, 43(167), 81-98.

[38] Norris, M., Paris, C. \& Winston, N. (2010). Second homes within Irish housing booms and busts: North - South comparisons, contrasts, and debates. Environment and Planning C: Government and Policy, 28(4), 666-680. DOI: 10.1068/c08134.

[39] Pallarès-Barberà, M., Tulla, A. F., Vera, A. (2005). Spatial loyalty and territorial embeddedness in the multi-sector clustering of the Berguedà region in Catalonia (Spain). Geoforum, 35(5), 635-649. DOI: 10.1016/j.geoforum.2004.03.004.

[40] Pallarès-Blanch, M. (2012). Natural Protected Areas and Rural/Local Development: A Sustainable Strategy in Remote Areas. Urbani izziv 23 (Suppl. 2), 93-96. DOI: 10.5379/urbani-izziv-en-2012-23-supplement-2-007.

[41] Pallarès-Blanch, M., Prados, M. J., Tulla, A. F. (2014). Naturbanization and Urban - Rural dynamics in Spain: Case study of new rural landscapes in Andalusia and Catalonia. European Countryside 6(2), 1-31. DOI: 10.2478/euco-2014-0008.

[42] Pallarès-Blanch, M. (2015). Women's eco-entrepreneurship: a possible pathway towards community resilience? Ager 18, 65-89. DOI: 10.4422/ager.2015.03.

[43] Pallarès-Blanch, M., Tulla, A. F., Vera, A. (2015). Environmental capital and women's entrepreneurship: A sustainable local development approach. Carpathian Journal of Earth and Environmental Sciences 10(3), 133-146.

[44] Paniagua, A. (2002). Urban-rural migration, tourism entrepreneurs and rural restructuring in Spain. Tourism geographies 4(4), 349-371. DOI: 10.1080/14616680210158128.

[45] Paniagua, A. (2008). The environmental dimension in the constitution of new social groups in an extremely depopulated rural area of Spain (Soria). Land Use Policy 25(1), 17-29. DOI: 10.1016/j.landusepol.2007.02.001.

[46] Pătroescu, M., Vânău, G., Niță, M. R., Iojă, C. \& lojă, A. (2011). Land use change in the Bucharest Metropolitan Area and its impacts on the quality of the environment in residential developments. Forum Geografic 10(1), 177-186. DOI: 10.5775/fg.20674635.2011.036.i. 
[47] Picu, V. M. (2011). Contributii la monografia comunei si Manastirii Comana. Tulsa, OK: Total Publishing.

[48] Popescu, C. \& Gavriş, A. (2012). The impact of the economic crisis in the IT\&C Industry Evidence from Bucharest. Journal of Urban and Regional Analysis 4(1), 35-49.

[49] Prados, M. J. (2009). Conceptual and methodological framework of naturbanization. In Prados, M. J.,ed., Naturbanization: New identities and processes for rural-natural areas (pp.11-28). London: Taylor \& Francis Group.

[50] Prados, M. J. \& del Valle, C. (2010). Naturbanización y cambios en la población de los espacios naturales de Doñana y Sierra Nevada. Documents d'Anàlisi Geogràfica 56(3), 437462.

[51] Sonderegger, R. \& Bätzing, W. (2013). Second homes in the Alpine Region. Journal of Alpine Research/Revue de Géographie Alpine. Hors-Série. DOI: 10.4000/rga.2511.

[52] Schaper, M. (2005). Understanding the green entrepreneur. In Schaper, M., ed., Making Ecopreneurs: Developing Sustainable Entrepreneurship (pp. 3-12). Aldershot: Ashgate.

[53] Shucksmith, M., Cameron, S., Merridew, T. \& Pichler, F. (2009). Urban-rural differences in quality of life across the European Union. Regional Studies 43(10), 1275-1289. DOI: $10.1080 / 00343400802378750$.

[54] Solana, A. M. (2010). Rural Gentrification in Catalonia, Spain? A Case Study of Migration, Social Change and Conflicts in the Empordanet area. Geoforum 41(3), 508-517. DOI: 10.1016/j.geoforum.2010.01.005.

[55] Tălângă, C., Zamfir, D. \& Stoica, I. V. (2011). Planification du territoire dans le context européen et national. In lanoş, I., Popa, N. \& Cercleux, A. L., ed., Éléments de planification territoriale et développement régional. Bucureşti: Editura Universitară.

[56] Tulla, A.-F., Pallarès-Barberà, M. \& Vera, A. (2009). Naturbanization and local development in the mountain areas of the Catalan Pyrenees. In Prados, M. J., ed., Naturbanization: New identities and processes for rural-natural areas (pp. 75-92), London: Taylor \& Francis Group.

[57] Ventura, F., Milone, P. \& Van der Ploeg, J. D. (2010). Understanding rural development dynamics. In Ventura, F. \& Milone, P., eds., Networking the Rural. The future of green regions in Europe (pp. 1-29). Assen: Royal Van Gorcum.

[58] Volery, T. (2002). Ecopreneurship: Rationale, current issues and future challenges. In Fueglistaller, U., Volery, T. \& Weber, W., eds., Radical Change in the World - will SMEs Soar or Crash? (pp. 541-553). St. Gallen: KMU HSG.

[59] Woods, M. (2011). Rural geography: Processes, responses and experiences in rural restructuring. London: SAGE Publications Ltd.

Other sources

[60] Comana NP Administration, http://www.comanaparc.ro/.

[61] Espon GROSEE Project (2013). Growth Poles in South East Europe, Scientific Report, ESPON \& University of Bucharest, Bucharest.

[62] Eurostat, last update 07.04.1.

[63] IDESCAT (2015). Institut d'Estadística de Catalonia, Generalitat de Catalonia, Barcelona.

[64] INE (2015). Instituto Nacional de Estadística, Gobierno de españa, Madrid.

[65] Management Plan of the Comana NP (2013), Comana NP Administration, available at http://comanaparc.ro/docum/continut.pdf.

[66] Romanian National Institute of Statistics, http://www.insse.ro. 
[67] Obra Social la Caixa (2015). Impacte econòmic i social dels Espais Naturals Protegits de Catalunya. Obra Social la Caixa report.

https://obrasociallacaixa.org/documents/10280/586356/impacto_economico_y_social_espa cios_naturales_protegidos_catalunya_metodologico_ca.pdf/4fc7f6e0-0a48-49f1-84a3d285270d90ba

[68] Peicea D. (2013a). Green infrastructure case study template. Comana wetlands, available at http://www.ceeweb.org/wpcontent/uploads/2013/11/Gl_case_study_Romania_Comana_we tlan ds. pdf.

[69] Peicea D. (2013b) Ecological restoration of Comana wetland, Giurgiu County, available at http://www.posmediu.ro/upload/pages/Prezentare\%20REBACO.pdf.

[70] Visiting Strategy of the Comana NP (2011), Comana NP Administration, available at http://comanaparc.ro/docum/Strategia_vizitare.pdf. 